
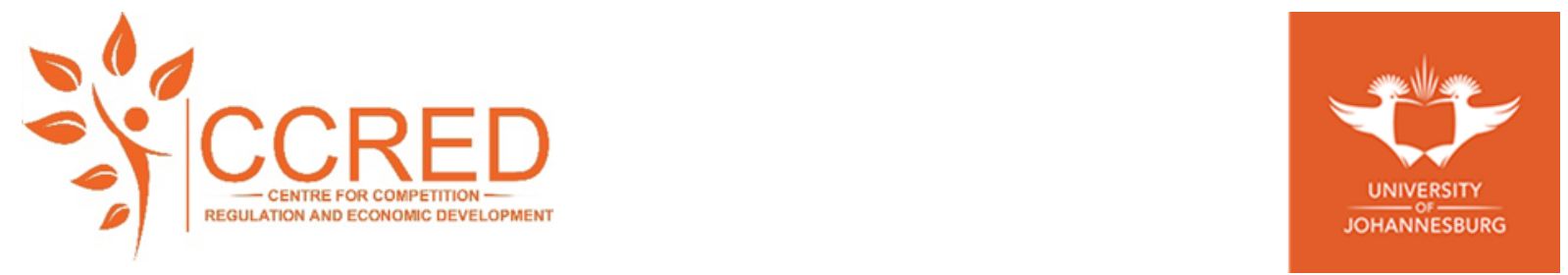

Working Paper 11/2018

\title{
STUCK IN THE MIDDLE: PREMATURE DEINDUSTRIALISATION AND INDUSTRIAL POLICY ${ }^{1}$
}

\author{
Antonio Andreoni \\ SOAS University of London and South African Research Chair in Industrial Development, \\ University of Johannesburg \\ aa155@soas.ac.uk \\ Fiona Tregenna \\ South African Research Chair in Industrial Development, University of Johannesburg
}

ftregenna@uj.ac.za

\begin{abstract}
Premature deindustrialisation is a threat to low- and middle-income countries, as it shrinks their opportunities for technological development, and their capacity to add value in global value chains and tradable sectors, thereby ultimately reducing their scope for productivity increases. This paper investigates the specific industrialisation challenges faced by middleincome countries today and provides global and regional evidence for the different premature deindustrialisation trajectories that countries have followed, with a specific focus on South Africa. Against this background, the paper develops an industrial policy framework highlighting three main aspects, namely (i) the importance of selecting appropriate instruments targeting specific production, technological and organisational challenges; (ii) the need for coordinating these instruments in coherent industrial policy packages; and, finally, (iii) the governance challenges that middle-income countries will face in managing these policy instruments. The challenges in implementing and governing complex industrial policy packages are highlighted by reviewing successful sectoral interventions in Brazil, China and Malaysia. Country and sectoral cases are finally used to extract a number of industrial policy implications for South Africa.
\end{abstract}

JEL Classifications: O14; O25; L16

Keywords: premature deindustrialisation; middle-income trap; industrial policy; South Africa; Brazil; China; Malaysia

\footnotetext{
${ }^{1}$ This paper forms part of a series of studies on the challenges of industrialisation undertaken by the Industrial Development Think Tank (IDTT). Established in 2017, the IDTT is supported by the Department of Trade and Industry (the dti) and is housed in the Centre for Competition, Regulation and Economic Development (CCRED) in partnership with the SARChl Chair in Industrial Development at the University of Johannesburg. The studies review trends of (de)industrialisation and assess the potential for structural transformation to drive growth, industrialisation and development in different sectors in South Africa. We would like to acknowledge Antonio Andreoni for reviewing the work and providing detailed comments.
} 


\section{Table of contents}

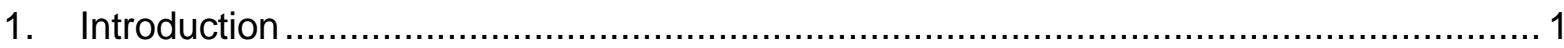

2. Middle-income Trap and Industrialisation Challenges ............................................... 2

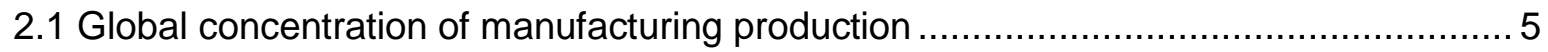

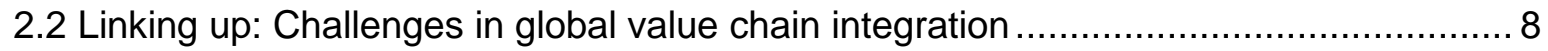

2.3 Keeping pace: Challenges of technological change and preconditions .................... 11

3. Premature deindustrialisation - South Africa in international comparative perspective. 13

4. Escaping from the Premature Deindustrialisation Trap: Industrial Policies for Middle-

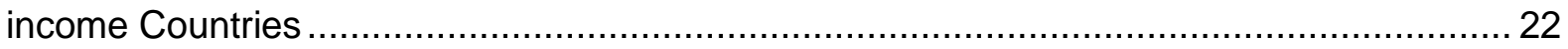

4.1 An industrial policy framework for middle-income countries: Instruments and

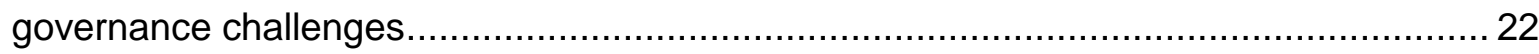

Governance challenges in the public sector ........................................................ 26

Governance challenges and political economy dynamics in the interaction between

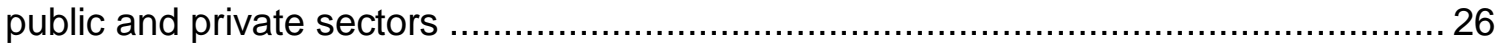

Governance challenges and political economy dynamics in the private sector .............27

4.2 Case study 1: Brazil and the industrialisation of agriculture .................................. 27

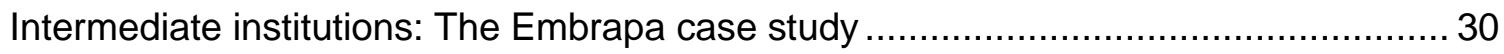

4.3 Case study 2: China and the manufacturing of an innovation economy ..................... 32

Technology and R\&D financing policies: The Innofund case study ............................. 34

4.4 Case study 3: Malaysia and the diversification of the economy …............................. 37

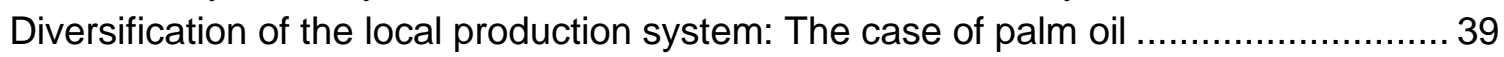

5. Concluding remarks and Implications for South Africa .......................................... 41

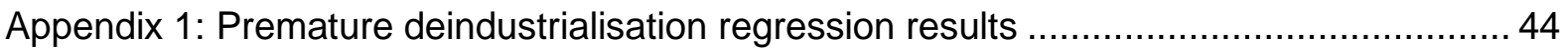

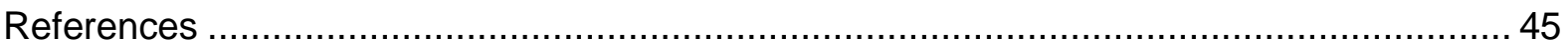




\section{List of figures}

Figure 1: South Africa, Brazil, China and Malaysia - GDP per capita 1960-2017 ............... 4

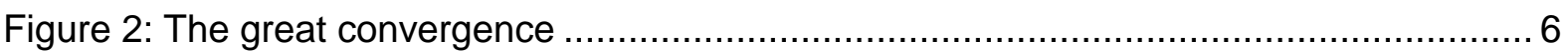

Figure 3: Domestic value added content of South African exports by major manufacturing

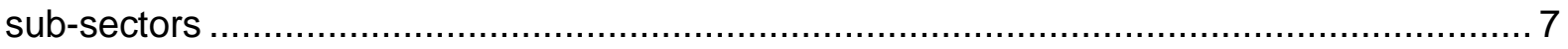

Figure 4: Backward integration in GVCs among major middle-income countries .................. 8

Figure 5: Capturing high-value niches and the need for multiple sets of complementary

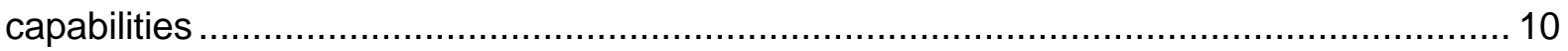

Figure 6: Tassey's classification of different technology types......................................... 12

Figure 7: Estimated relationship between GDP per capita and manufacturing share of

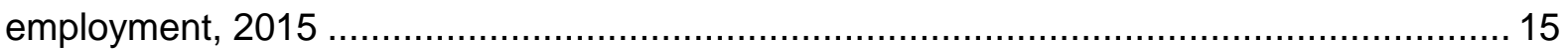

Figure 8: Characterisation of international trends in deindustrialisation ........................... 17

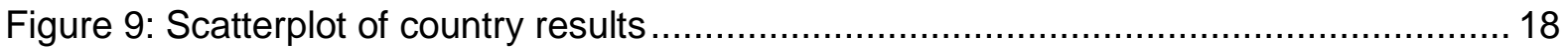

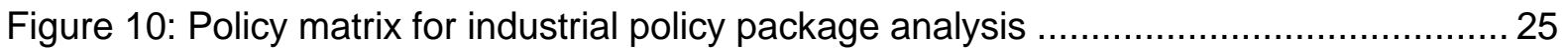

\section{List of tables}

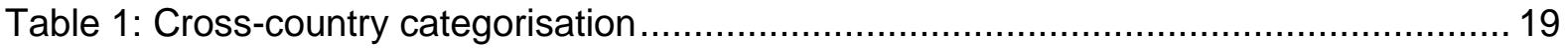

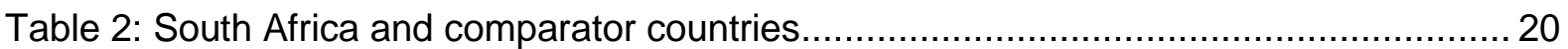

Table 3: Possible premature deindustrialisers, 2005-2015 ............................................. 21

Table 4: An industrial policy toolbox for middle-income countries....................................... 23

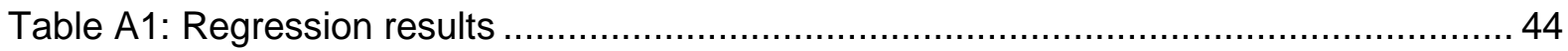




\section{Introduction}

Over the past two decades, the world economy has undergone profound structural transformations. Despite a number of catching-up economies having registered fast economic growth during this period, world industrial production has remained highly concentrated. Today, fewer than twenty countries control $80 \%$ of the world manufacturing value-addition activities. Many low- and middle-income countries are not part of this group of industrialised nations, and indeed many of those countries that have managed to reach middle-income status have shown signs of premature deindustrialisation. South Africa is one of these middleincome countries.

Premature deindustrialisation is a threat to low- and middle-income countries, as it shrinks their opportunities for technological development, and their capacity to add value in global value chains and tradable sectors, thereby ultimately reducing their scope for productivity increases. In order to reverse this trend and run the risk of falling behind in the global industrial landscape, appropriate packages of industrial, technological and innovation policies have to be deployed. These are essential economic policy tools for escaping the middle-income trap, increasing domestic value addition and, more critically, reversing the processes of premature deindustrialisation.

The effectiveness of industrial policy in addressing premature deindustrialisation in middleincome countries critically depends on the specific features of the industrial system. Indeed, countries that are traditionally classified in the group of middle-income countries are highly heterogeneous with respect to their premature deindustrialisation experiences. Benchmarking South Africa against international industrial performance and policy experience offers an opportunity to identify those countries facing similar challenges and to assess the extent to which their policy responses are feasible in the South African context, both from economic and political economy perspectives.

This paper investigates the specific industrialisation challenges faced by middle-income countries today and provides global and regional evidence for the different premature deindustrialisation trajectories that countries have followed, with a specific focus on South Africa. Against this background, the paper develops an industrial policy framework highlighting three main aspects, namely (i) the importance of selecting appropriate instruments targeting specific production, technological and organisational challenges; (ii) the need for coordinating these instruments in coherent industrial policy packages; and, finally, (iii) the governance challenges that middle-income countries will face in managing these policy instruments.

Particular emphasis is placed on the identification of clusters of industrial policy instruments that have been implemented successfully in middle-income countries. The challenges in implementing and governing complex industrial policy packages through different stages of industrialisation are highlighted by reviewing three country cases, namely Brazil, China and Malaysia. In-depth analysis of successful sectoral interventions for each of these countries are also presented to highlight specific design, implementation and enforcement mechanisms adopted by these countries. The paper concludes by sketching a number of industrial policy implications for South Africa, in particular with respect to the premature deindustrialisation challenges and the need for a more integrated industrial policy framework. 
Section 2 discusses the issue of the 'middle-income trap' and the challenges that middleincome countries face in industrialising during the current period. Particular attention is given to the concentration of industrial production among a small number of countries, to challenges around integration into global value chains (GVCs), and to the challenges of keeping pace with technological changes. Section 3 presents an empirical analysis of selected global evidence on the phenomenon of premature deindustrialisation, situating South Africa in an international comparative perspective. Section 4 focuses on industrial policy options for middle-income countries to avoiding (or reversing) premature deindustrialisation and escaping the middle-income trap. This draws on three diverse country case studies: Brazil, China and Malaysia. Section 5 concludes by considering policy implications of the analysis for South Africa.

\section{Middle-income Trap and Industrialisation Challenges}

The world's middle-income countries (MICs) are a heterogenous group of countries divided in two main groups, that is lower middle-income economies (those with a GNI per capita between $\$ 1006$ and \$3 955) and upper middle-income economies (those with a GNI per capita between $\$ 3956$ and $\$ 12$ 235). Middle-income countries are home to five of the world's seven billion people (and $73 \%$ of the world's poor people) and generate one third of global GDP (World Bank, 2018).

In recent years, a number of low and high middle-income countries have witnessed a slowdown of their economic growth after reaching middle-income levels. Indeed, as stressed by the World Bank, only 13 of 101 middle income economies in 1960 had become high-income economies by 2008 (World Bank, 2013). This phenomenon - characterised as the 'middleincome trap' - has raised significant concerns among policymakers in countries such as China, Brazil, Malaysia and South Africa.

The concept of the 'middle-income trap' was introduced in a research report by the World Bank titled An East Asian Renaissance: Ideas for Economic Growth (2007). In this report, Gill and Kharas coined the idea of the middle-income trap in the following passage:

In the absence of economies of scale, East Asian middle-income countries would face an uphill struggle to maintain their historically impressive growth. Strategies based on factor accumulation are likely to deliver steadily worse results, which is a natural occurrence as the marginal productivity of capital declines. Latin America and the Middle East are examples of middle-income regions that, for decades, have been unable to escape this trap (Gill \& Kharas, 2007:18; italics added).

Despite the term 'middle-income trap' itself largely remaining under-theorised, it has since been used widely in the development literature and policy discourse to describe stagnant growth in both absolute and relative terms. It suggests a situation of long-term stagnating equilibrium in terms of per capita income and, thus, the failure to maintain sustained economic growth towards the high income level of developed countries. For example, Arias and Wen (2015) define an 'income trap' as the phenomenon of an economy's aggregate income per capita failing to grow faster than that of the US, which is taken as benchmark of the developed world. A situation in which an economy's income per capita relative to the US remains 
constantly and substantially below $50 \%$ is called a (relative) middle-income trap. These authors refer to (relative) low-income trap (or poverty trap) in cases when it remains significantly below $10 \%$.

An increasing number of studies have attempted to identify and measure the middle-income trap and its global structural dynamics (see Wade (2016) for a review of these studies). In particular, they have focused on providing different explanations for the underlying causes of this phenomenon. Among them, a number of specific industrialisation challenges faced by middle-income countries have been identified.

First, and in a relatively general sense, scholars have pointed to the challenges that middleincome countries face in sustaining labour productivity growth over a long period of time. For example, Justin Lin (2016:6) suggests that "[t]he middle-income trap is a result of a middleincome country's failure to have a faster labor productivity growth through technological innovation and industrial upgrading than high-income countries".

Second, other scholars (see for instance Lee, 2013; Williamson, 2012) argue that a source of the middle-income trap is the difficulty of these countries competing with low-wage and largescale exporters. At the same time, they cannot compete with technologically advanced economies because their industrial capabilities are not yet sufficiently developed to give them a competitive advantage.

Third, if we embrace the idea that manufacturing industries play a critical role in boosting productivity, value addition and technological change, premature deindustrialisation could be another factor responsible for the phenomenon of the middle-income trap. Countries experience premature deindustrialisation when deindustrialisation has begun at a lower level of GDP per capita, and/or at a lower level of manufacturing as a share of total employment and GDP, than is typically the case internationally. Many of the cases of premature deindustrialisation are in sub-Saharan Africa, in some instances taking the form of 'preindustrial deindustrialisation' (Tregenna, 2015).

According to various indicators of industrial competitiveness, South Africa is stuck in the middle-income countries segment, and has shown signs of an ongoing process of premature deindustrialisation. Over several decades, the annual growth rate of the manufacturing sector has slowed down dramatically, thereby affecting the absolute manufacturing value addition produced in the country. As a result of this premature deindustrialisation process, if we benchmark South Africa's export performances against that of other middle-income countries, we also find that gross export value has increased since 2000, but at a much slower pace than major comparator countries.

Moreover, trade relationships between South Africa and the new industrial giants have mainly reinforced the ongoing structural processes of premature deindustrialisation. Over the past decade, China and India have emerged as the top two destinations of South Africa's intermediate exports, while China became South Africa's largest supplier of imports in 2009. By 2011, imports from China were already above $12 \%$ of total imports and were overwhelmingly of manufactured goods, while South Africa's exports remained mainly composed by natural resources - i.e. mining and basic metals. 
Figure 1 compares the evolution of South Africa's GDP per capita with that of the three comparator countries discussed here (Brazil, China and Malaysia). This throws South Africa's long-term structural problems into stark relief. In 1960 South Africa had by some distance the highest level of GDP per capita in the group. Brazil's GDP per capita was $76 \%$ that of South Africa, that of Malaysia was $29 \%$, and that of China just $4 \%$ that of South Africa. South Africa retained its leading position until 1972, after which it was overtaken by Brazil. Malaysia overtook South Africa in 1993, and China will overtake South Africa this year.

It is true that virtually all countries would show up poorly when benchmarked against China's long-run growth miracle, especially the past three decades of unprecedented rapid and sustained growth in China. Yet South Africa performs poorly when compared not just against the comparator countries shown here, but against all relevant country groupings and aggregates. This underscores the long-term structural deficiencies of South Africa's economy and growth trajectory, and the extent to which it is stuck in its middle-income position and in fact falling down the global rankings in GDP per capita.

Figure 1: South Africa, Brazil, China and Malaysia - GDP per capita 1960-2017

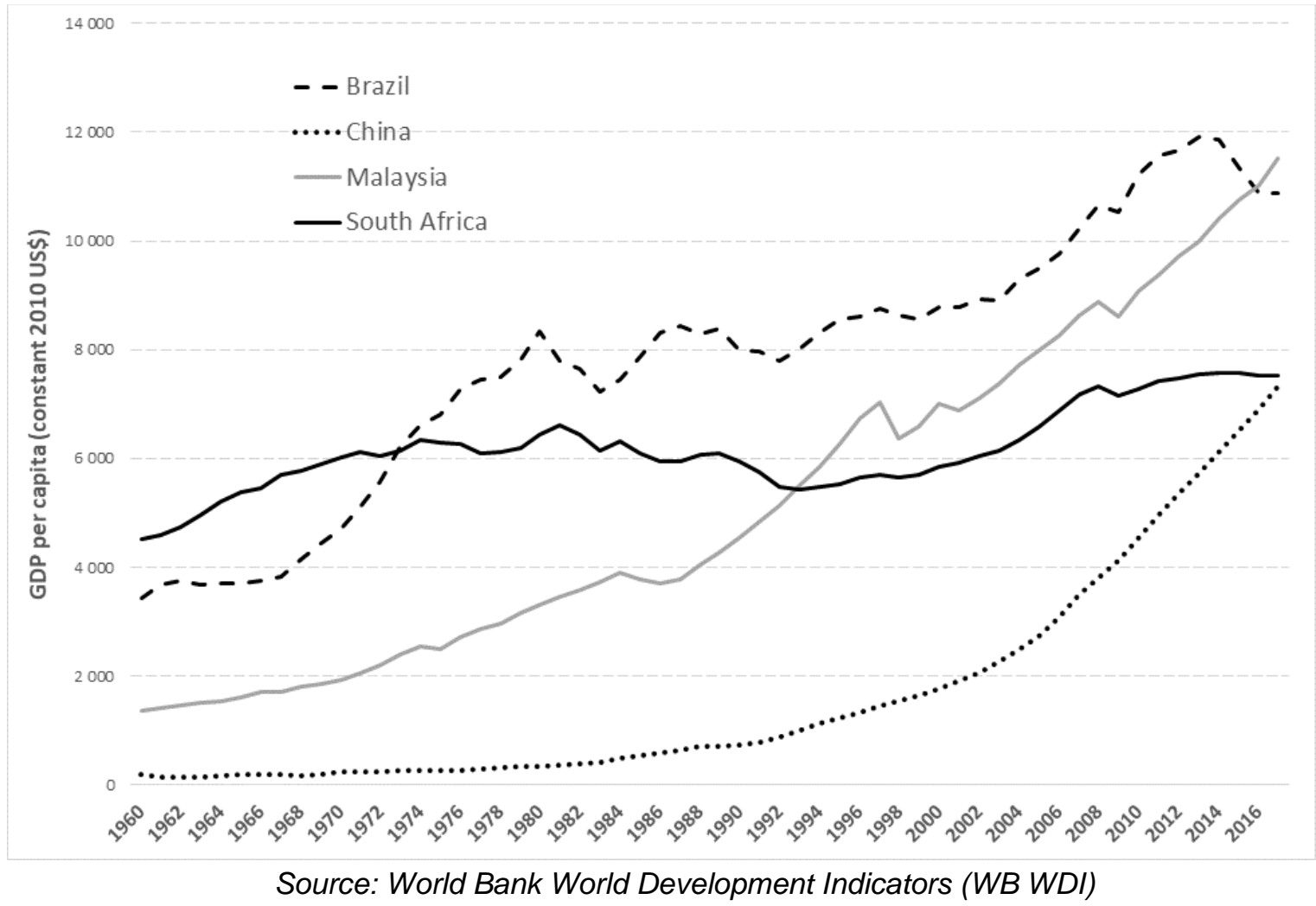

The literature on the middle-income trap thus points to several industrialisation challenges that are intertwined, and that reinforce each other in different ways along different countries' structural trajectories. These challenges also present potential opportunities for middleincome countries to industrialise and develop. In the analysis that follows, we suggest the need to go deeper in our understanding of these industrialisation challenges by considering the specific structural factors responsible for the middle-income trap - 'global concentration', 'linking up' and 'keeping pace' - and explicitly distinguishing different 'premature deindustrialisation trajectories'. Indeed, capturing this set of factors, and how they unfold in 
different countries along different structural trajectories, is a key step towards designing appropriate industrial policy for middle-income countries.

\subsection{Global concentration of manufacturing production}

Over the last two decades, the global industrial landscape has been reshaped by profound structural transformations. These dramatic transformations started in the mid-1990s and led to the 'great convergence' between the most industrialised nations and a relatively small group of fast catching-up economies.

Between 1995 and 2010, the G7 countries lost significant shares of value addition. In particular, their shares in world manufacturing value added (WMVA) registered a major decline. In 1995, the two leading industrial nations - the United States and Japan - together contributed more than $40 \%$ of WMVA, while Germany, Italy, France and the UK contributed another $25 \%$. South Korea and Canada controlled another $2 \%$ of WMVA each at that time. This means that fewer than ten nations controlled more than $70 \%$ of the world manufacturing landscape in 1995. By 2011, less than 15 years later, all the G7 countries together accounted for only $40 \%$ of the WMVA, although their manufacturing value added in absolute terms kept increasing steadily until the 2007 financial crisis.

During the same period, between 1995 and 2010, emerging economies increased their total value addition from $13 \%$ to $27 \%$, and their joint WMVA shares from $18 \%$ to $36 \%$ (Figure 2 ). This process of convergence has been driven by the rise of the new industrial superpower China - and a group of fast catching-up economies. China moved from contributing less than $5 \%$ of WMVA in 1995 to $10 \%$ in 2005, and more than $20 \%$ in 2011 , to reach a peak of almost $23 \%$ in 2014 . As a result, China's share in world value-added exports surged to $17 \%$ in 2014 , seven percentage points ahead of the second world-leading exporter - Germany - and more than double that of the United States. 
Figure 2: The great convergence

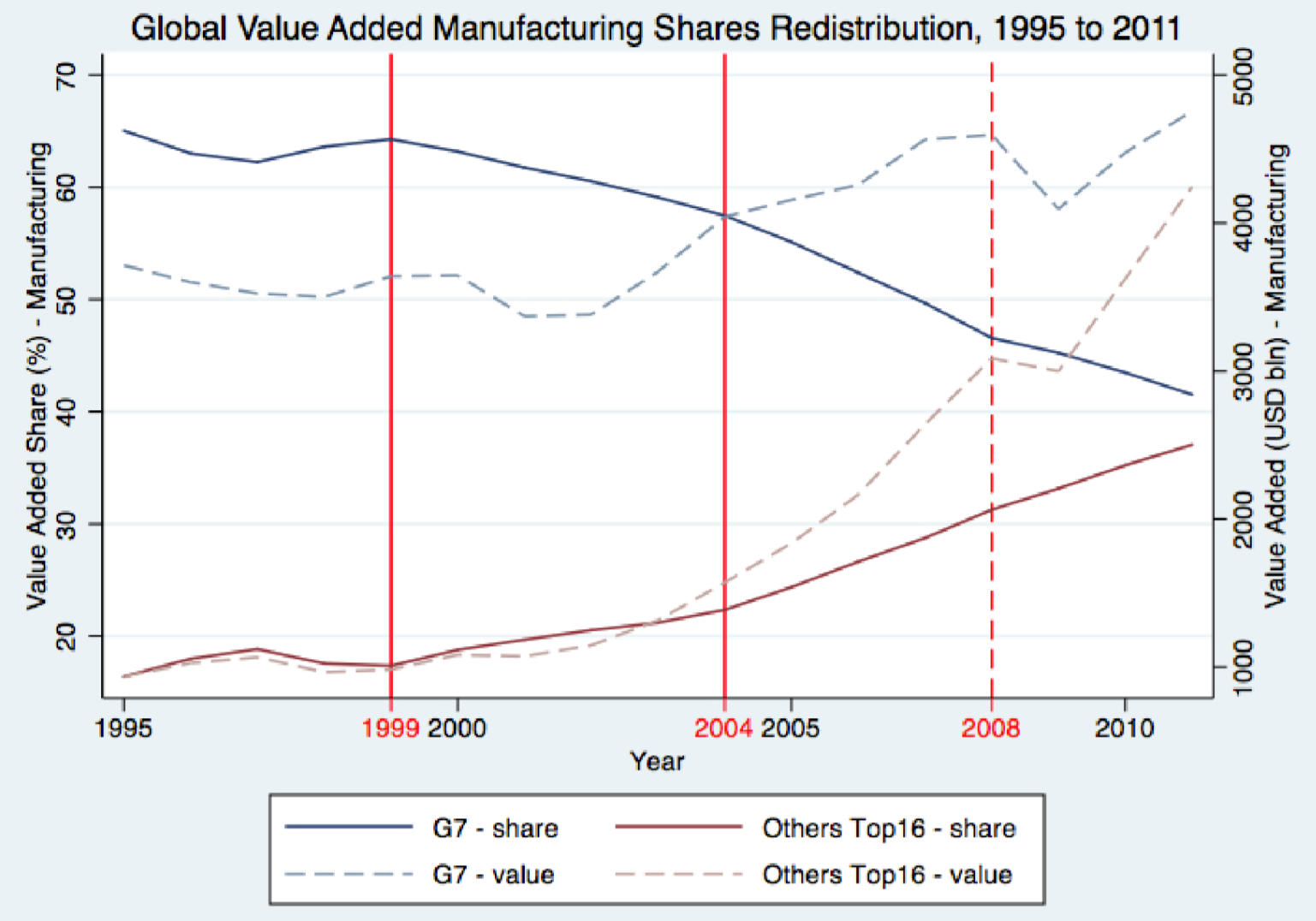

Source: Authors, based on TiVA OECD

Note: "OtherTop16" includes countries other than G7 which are in the top16 for Manufacturing Value Added produced in 2011: China, Korea, Brazil, India, Russia, Indonesia, Mexico, Spain, Turkey. Taken all together - G7 plus OtherTop16 - only 16 countries account for the $80 \%$ of the world Total MVA produced in 2011.

Between 2000 and 2010, India, Russia and Brazil almost doubled their WMVA shares to overcome the $2.5 \%$ threshold in WMVA shares, while Indonesia approached almost $2 \%$ by 2010. A number of upper middle-income countries - including Malaysia and South Africa were only marginally involved in this great convergence, as reflected in their WMVA shares. Indeed, some of them are today facing a middle-income trap often linked to processes of premature deindustrialisation.

We thus see ongoing concentration of manufacturing production amongst a relatively small group of countries. The G7 countries no longer command the same high share of global manufacturing as was previously the case, yet their share remains high. The next tier of emerging manufacturers - shown here as the group of 16 - have to some extent closed the gap with the advanced economies. Even this emerging group is itself highly concentrated. Still, it demonstrates the possibilities of breaking into the group of leading manufacturing nations.

Against this persistent concentration in the global industrial landscape, South Africa has faced a fundamental challenge in increasing its domestic value addition (DVA) in manufacturing industries and exported products. DVA in manufacturing products captures the extent to which 
a country is able to add value to its produce. The value addition can be the result of several types of activity, including extracting and processing raw materials; designing a product; producing components; integrating or assembling product systems; and adding services to products downstream in the value chain.

To capture the extent to which a country has engaged in value addition activities, it is critical to measure only the net value addition, thus excluding the value that results from buying goods and services from abroad. In South Africa, the net DVA declined among all major manufacturing subsectors between 1995 and 2008 (Figure 3). Some recovery was registered after 2008, for example in the machinery and equipment industries. Direct exports by the mining industry generated the greatest source of domestic value added in 2011, accounting for $24.6 \%$ of the total value added of exports. The next three most important industries were wholesale, retail \& hotels (10.2\%), basic metals (9.3\%), and transport \& telecommunications $(5.4 \%)$.

\section{Figure 3: Domestic value added content of South African exports by major manufacturing sub-sectors}

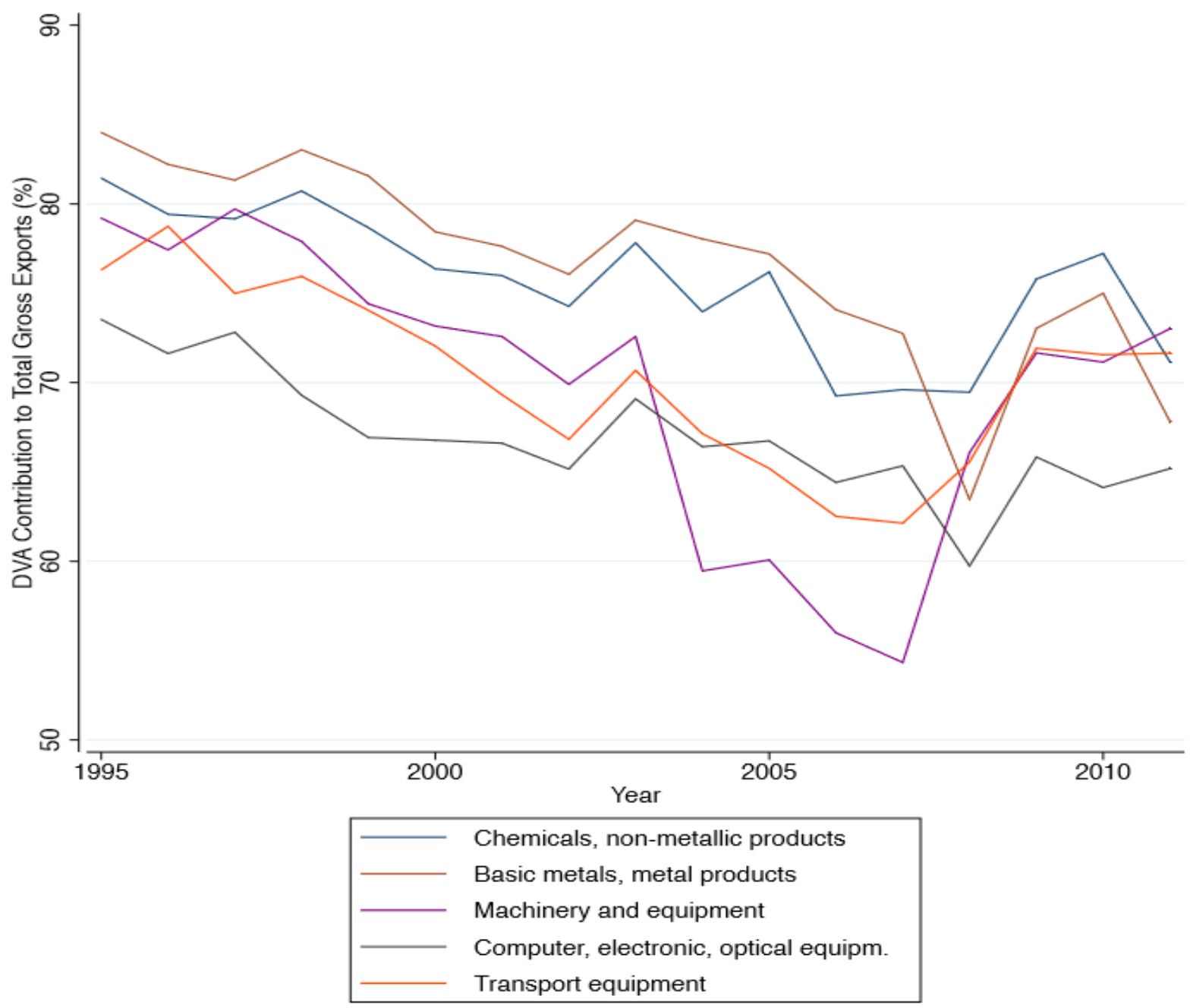

Source: Authors, based on TIVA 


\subsection{Linking up: Challenges in global value chain integration}

Domestic value-added performances reflect the extent to which countries have been able to build up their industrial capabilities and take advantage of the opportunities offered by forward integration into global value chains (GVCs). Between 1990 and 2010, African countries experienced limited gains from GVC integration and declining forward integration (and domestic value addition) in international trade. While the value of world imports more than doubled during the 2000s, with intermediate goods making $65 \%$ of world imports in 2011 , much of Africa's participation in GVCs has developed in upstream production (backward integration). This upstream GVC specialisation has been coupled with a declining downstream integration since 1995. South Africa has seen an increase in backward integration, measured as the share of foreign value added in export, from 17\% in 1995 to 30\% in 2011 (Figure 4).

\section{Figure 4: Backward integration in GVCs among major middle-income countries}

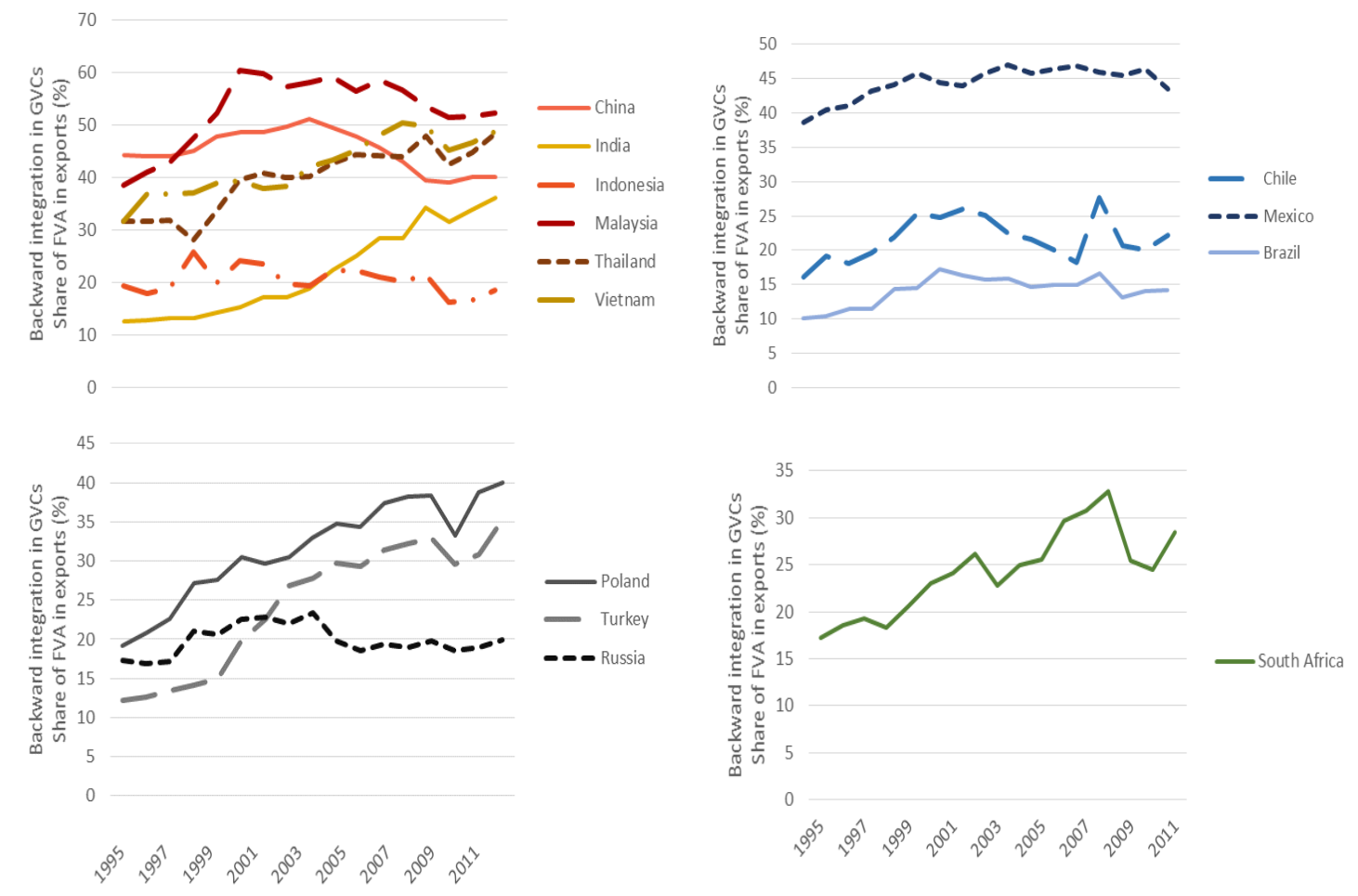

Source: Authors, based on TIVA

Middle-income countries like South Africa face the difficulty of moving into more technologically sophisticated segments of GVCs, often remaining stuck in the middle-income trap. By middle-income countries joining RVCs or GVCs, focusing on the production of lowvalue added parts and components, might risk 'de-linking domestically' and hollowing out of the domestic manufacturing sector. Under these conditions, a combination of weak productivity growth and rising labour costs, or the emergence of alternative lower-cost locations, might lead to declining profitability, disengagement by the lead firm and a further weakening of domestic productive capacity.

In contrast, by linking up local producers and local supply chains to international companies and system integrators - local production system development - domestic companies can 
capture international demand and learn from exporting (Andreoni, 2018). South Korea and Taiwan, between 1970 and 1990, and China in the 1980s and 1990s, all started their industrialisation by linking (backwards) to global supply chains and adding value (forwards) in electronics and other industries, starting in particular from those characterised by shorttechnology cycles. With the expansion of the local production system through downstream (forward) integration, more opportunities for backward integration also open up, as domestic companies will start importing more intermediate goods while diversifying their export baskets.

Global value chain upgrading is the process of improving the ability of a firm or an economy to move to more profitable and/or technologically sophisticated capital and skill-intensive economic niches. Upgrading can take different forms, including:

i. Process upgrading, which typically refers to improved production methods that transform inputs into final products more efficiently through the reorganisation of production or the introduction of superior technology;

ii. Product upgrading, which is moving into more sophisticated product lines in terms of higher unit-value products, rather than moving to a different part of the value chain;

iii. Functional upgrading, which involves performing new, superior functions in the chain, such as design or marketing, or abandoning existing low value-added functions to focus on higher value-added activities;

iv. Intersectoral upgrading, which entails applying the competence acquired in a particular function or industry to move into a new sector. For instance, Taiwan used its competence in producing televisions to make monitors and then to move into the computer sector.

The GVC framework stresses the opportunities for companies (and local production systems) to specialise in specific production tasks or components, preferably 'high-value niches', while avoiding the building up of entire vertically integrated industrial sectors or blocks of industries (Gereffi, 2013; Milberg \& Winkler, 2013). The idea of a selective form of specialisation in tasks, driven by capturing value opportunities, would encourage companies to focus on activities such as research and development (R\&D), design and downstream post-sale services, while dismissing more 'traditional' (at least so perceived) manufacturing processes.

Although this literature has revealed important aspects of modern manufacturing, it also presents a number of limitations. Two of these are critical for the development of our understanding of the challenges facing middle-income countries, while more issues have been raised in other contributions (Andreoni, 2018; Chang \& Andreoni, 2016).

First, in order to capture 'high-value niche' opportunities along the value chain via tasks specialisation, companies often require multiple sets of complementary production capabilities that cut across multiple stages of the value chain and different technology domains (Figure 5). This is increasingly so in the case of complex high-tech high-value products or components. For example, the task specialisation in design often requires direct access in the same local industrial ecosystems to specific production capabilities for prototyping and manufacturing to scale up products and processes. This means that task specialisation requires the identification of complementary sets of capabilities that constitute the technology platform underpinning the task or set of related tasks. 
Traditionally, these sets of capabilities were developed within vertically integrated firms (Penrose, 1959), or within industrial blocks. ${ }^{2}$ The possibility for firms in a certain location to develop a competitive advantage in a certain task/stage, and thus to capture a 'high-value niche', will depend on complementary sets of different capabilities whose development might require involvement in more than one stage of the same (or other) value chains. In successful industrial ecosystems, like the Boston route (Best, 1990, 2013) and the Emilia Romagna region (Andreoni, 2018a, 2018b; Andreoni et al., 2017), these complementary capabilities have developed along different cycles of industrial transformation and the renewal of vertically integrated firms, backed up by a dense network of local specialised suppliers and contractors.

\section{Figure 5: Capturing high-value niches and the need for multiple sets of complementary capabilities}

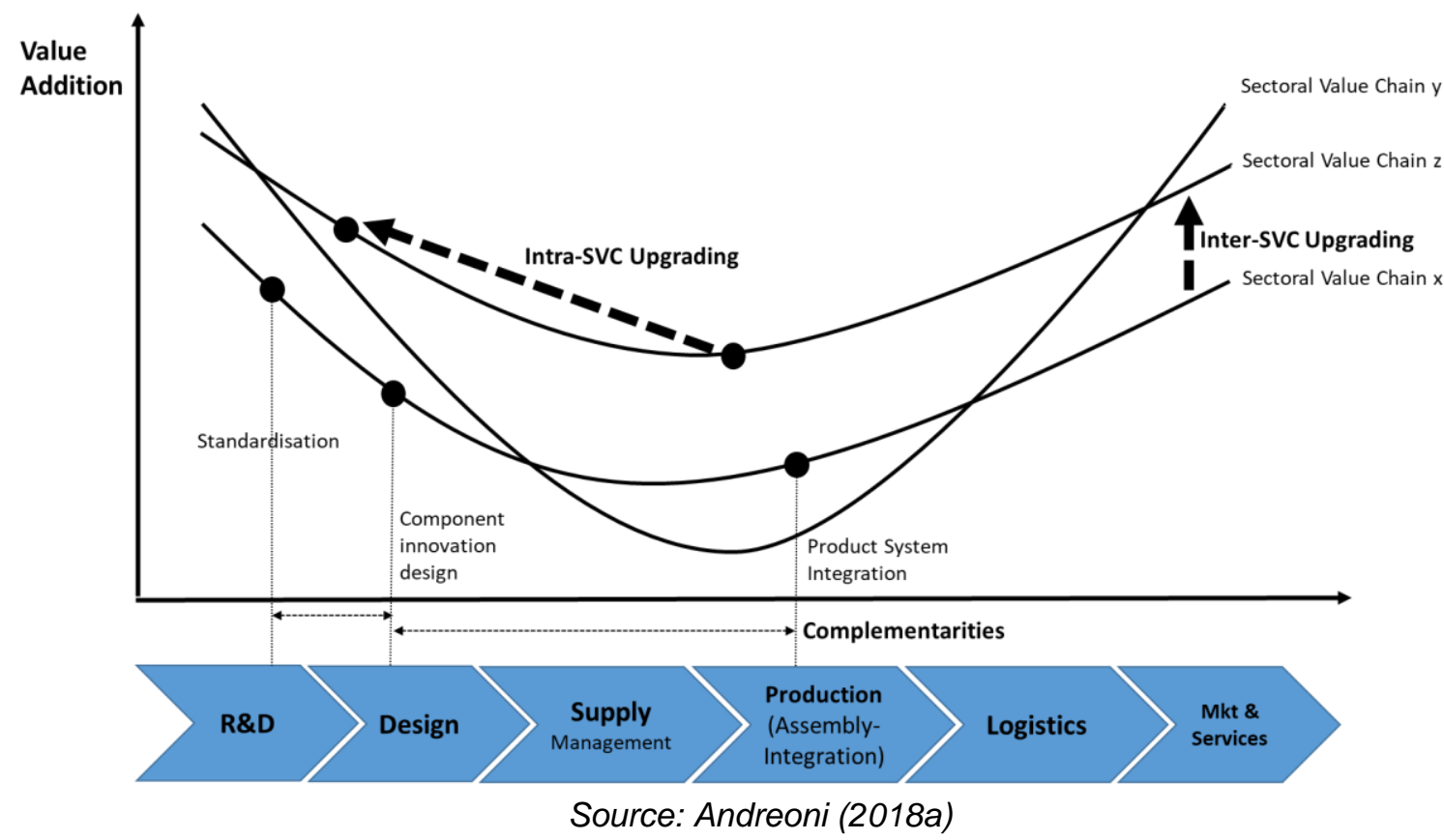

A second problem in the GVC approach is that it has increasingly become a-sectoral, that is, it has led to the undermining of a number of specificities of industrial sectors (or groups of industrial sectors). Given the structural heterogeneity characterising industries, in particular manufacturing sectors (Andreoni \& Chang, 2016), we can expect that the value creation and capture opportunities are in fact distributed in different ways across value chains in different sectors. This is why the complete abandonment of the sectoral heuristic might be problematic. In other terms, while vertically integrated sectors are poor heuristics to understand the modern network/value chain mode of production, these networks and value chains still are fundamentally heterogeneous and present specific features in terms of their modularity, their

\footnotetext{
${ }^{2}$ According to Dahmen (1989:132), the development block "refers to a sequence of complementarities which by way of a series of structural tensions, i.e., disequilibria, may result in a balanced situation". The emergence of development blocks may be either the result of ex-post 'gap filling', whereby a 'structural tension' or bottleneck is solved, or the result of an ex-ante 'creation of markets' by coordinated entrepreneurial activities or 'economic planning' by government institutions. As documented in the history of the steel industry (Dahmen, 1989) or in the empirical analysis of other Swedish industries (Enflo et al., 2007 adopt cointegration analysis), development blocks trigger the cumulative dynamics of regional differentiation in technological and other factor endowments.
} 
length and distribution across countries, and the underpinning set of technological capabilities. The value chain 'shape' and 'length' depend on multiple factors, including specific sectoral and organisational features, as well as the combination of complementary capabilities - i.e. technology platforms - required to execute tasks in the different stages of the chain, and these tasks tend to be different across sectors. For example, the aerospace and medical device sectors are both characterised by complex technology platforms, as both produce multithousands of 'critical system products'.

Intersectoral upgrading is becoming an increasingly important process, given that modern, high-value manufacturing activities rely on cross-cutting technology systems. Different technology systems, such as biotechnologies, advanced materials, microelectronics and automation, enable multiple production activities (also processes and tasks as their components) in different manufacturing industries. By nurturing the development of these complementary sets of capabilities, the scope for technological innovation within and across sectors - thus intra- and inter-sectoral upgrading - tends to increase and new development trajectories are potentially built.

\subsection{Keeping pace: Challenges of technological change and preconditions}

Technological change at the innovation frontier - the so-called Industry 4.0 - has increasingly been recognised by lower- and middle-income countries as a critical competitive factor for global value chain upgrading and a leapfrogging opportunity. Sectoral value chains are based on different technology platforms integrating various types of technologies and technology systems (see Figure 6). As eloquently documented in Tassey (2010:6):

Most modern technologies are systems, which means interdependencies exist among a set of industries that contribute advanced materials, various components, subsystems, manufacturing systems and eventually service systems based on sets of manufactured hardware and software. The modern global economy is therefore constructed around supply chains, whose tiers (industries) interact in complex ways.

This means that some of these technology platforms underpin the production processes of closely related industrial sectors as well as different product-value segments within the same industrial sector. Technologies are thus linked by a set of dynamic interlocking relationships spanning across sectors and value-product segments. 
Figure 6: Tassey's classification of different technology types

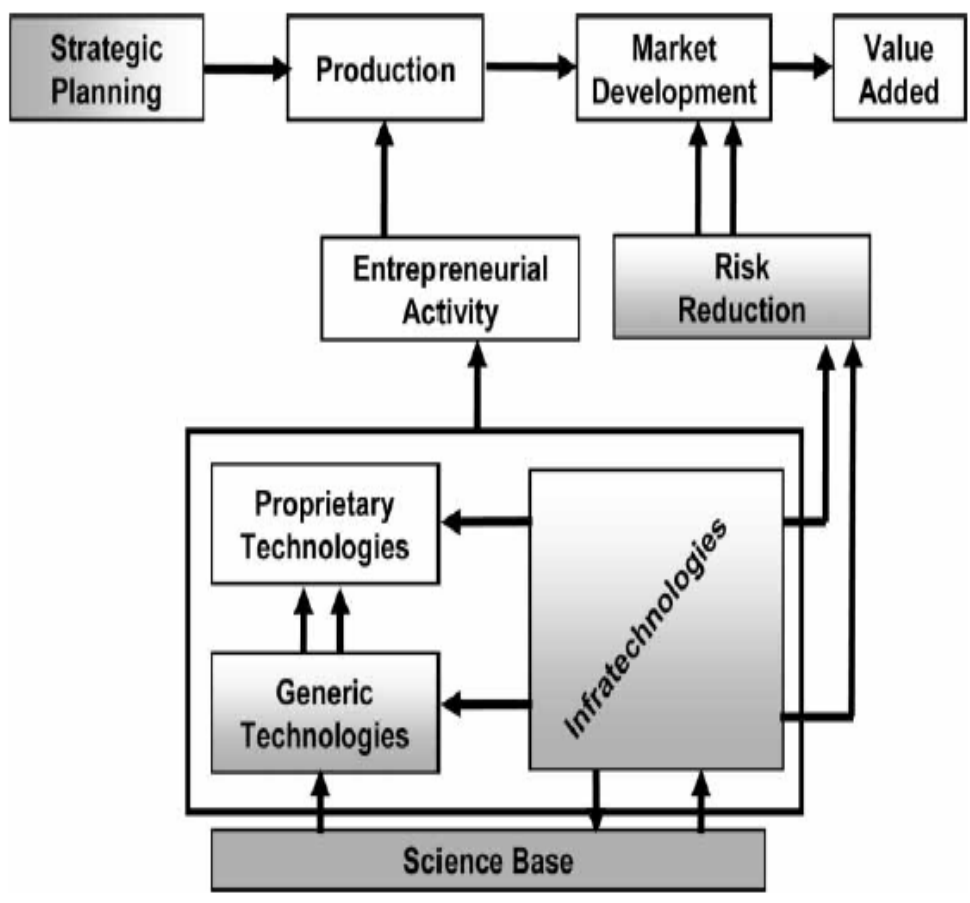

Source: Tassey (2007)

The emergence of these dynamic interdependencies, as well as the technology transition from one type of technology platform to another, tends to follow cyclical patterns. Often, these technology transitions open new value-product segment opportunities for business organisations. The existence of technology cycles is particularly evident in relation to technology transitions underpinning firms' shifts from mature product segments to higher value-product segments within the same industrial sector (Andreoni et al., 2017).

The identification (and development) of key technology systems can follow different criteria (and policies) associated with different technology properties:

i. their being 'transversal', that is, the extent to which they are deployed in multiple sectoral supply chains

ii. their degree of 'embeddedness', that is, the extent to which they play a critical role within integrated technology systems

iii. their 'quality-enhancing potential', that is, the extent to which they allow increasing quality products and their functionalities

iv. their 'productivity-enhancing potential', that is, the extent to which they affect production processes' productivity

v. their being 'strategic', in terms of facing major social and economic future challenges or markets

In the economic literature, technologies and technology systems responding to a number of these properties (especially the transversal one) have been associated with the concept of general purpose technologies (GPTs). GPTs have been studied especially with reference to the emergence of new technology paradigms and their broader impact on the economy (for a review, see Bresnahan, 2010; Jovanovic \& Rousseau, 2005). 
Starting from 2010, European Union (EU) technology and industrial policy has identified and focused its interventions on a set of key technologies and technology systems characterised by more than one of the properties highlighted above. These are:

- Advanced materials (AM)

- Advanced manufacturing systems (AMS)

- Industrial biotechnology (IB)

- Photonics (PH)

- Micro- and nano-electronics (MNE)

- Nanotechnology (NT)

Given their transversal nature, high potential and strategic role, these technologies have been called Key Enabling Technologies (KETs).

KETs are knowledge and capital-intensive technologies associated with high research and development $(R \& D)$ intensity, rapid and integrated innovation cycles, high capital expenditure and highly-skilled employment. Their influence is pervasive, enabling process, product and service innovation throughout the economy. They are of systemic relevance, multidisciplinary and trans-sectorial, cutting across many technology areas with a trend towards convergence, technology integration and the potential to induce structural change.

KETs are technologies/technology systems underpinning the development of today's most complex products - in particular smart devices that are able to interact with their users, collecting and using data (Internet of Things, loT) and performing multiple services. KETs are also central to different technology platforms underpinning supply chains of different types. Thus, they are deployed transversally within the industrial ecosystem, and across the different types of sectoral supply chains listed above.

Middle-income countries like South Africa run the risk of undermining the 'technological preconditions' that have to be met in order to capture value opportunities from technological change. For example, to make investments in ICT and digital solutions valuable, investments in the production capacity and hardware and organisational capabilities must be in place. In particular, the integration of digital technologies and networks with robotics and autonomous systems requires investments in key technology sub-systems and components, including automation and $\mathrm{m} 2 \mathrm{~m}$ technologies, embedded software, sensors and human interfaces, and augmented reality. These emerging technologies are expected to reshape the industrial plant of the future, making processes faster and more responsive, while reshaping the nature of jobs and skills.

\section{Premature deindustrialisation - South Africa in international comparative perspective}

In this section, we empirically analyse deindustrialisation trends across countries. This explores the patterns and dynamics of deindustrialisation internationally, in particular premature deindustrialisation, and locates South Africa in the context of these trends. 
First, we econometrically estimate the relationship between countries' GDP per capita and their shares of manufacturing in total employment. Second, based on this simple regression analysis, we identify the level of GDP per capita and share of manufacturing in total employment associated with the 'turning point', at which the share of manufacturing levels off and begins to decline. Third, we conceptualise a characterisation of possible country experiences based on countries' changes in share of manufacturing in total employment, and on whether their actual share of manufacturing in total employment is higher or lower than the regression analysis would predict. Fourth, we categorise countries based on these two dimensions. Finally, combining this with data on countries' 2015 level of GDP per capita and manufacturing employment share allows us to identify possible premature deindustrialisers. Throughout, particular attention is drawn to the case of South Africa.

We begin this part of the analysis by analysing the relationship between GDP per capita and the share of manufacturing in total employment. This part of the method follows Rowthorn (1994), Palma, $(2005,2008)$ and Tregenna (2015). Rowthorn (1994) identifies an inverted-U relationship between countries. That is, at higher levels of GDP per capita, the share of manufacturing in total employment typically rises, up to a turning point associated with a particular level of GDP per capita and share of manufacturing employment, after which manufacturing accounts for a declining share of total employment. Naturally, this is a stylised pattern based on data for many countries, and countries will inevitably have either a higher or lower actual employment share than would be predicted based on the regression analysis.

We estimate the share of manufacturing employment in total employment as a function of GDP per capita and GDP per capita squared (all in natural logs). The inclusion of the squared term takes account of the expected non-linear relationship between the explanatory and independent variables. The analysis uses only the shares of manufacturing in total employment. $^{3}$

Data on GDP per capita and population is from the United Nations (UN) Main National Accounts database (UNMNA). ${ }^{4}$ Data on manufacturing share of employment is taken from the International Labour Organisation (ILO) ILOSTAT database. ${ }^{5}$ The final sample comprises 148 countries, with excellent coverage across regions and across levels of development. ${ }^{6}$

\footnotetext{
${ }^{3} \mathrm{~A}$ possible extension would also include the share of manufacturing in GDP. Both conceptually and empirically, it is important to consider both employment and GDP when analysing deindustrialisation (see Tregenna, 2009). Using employment shares only can give an incomplete and potentially misleading picture, especially where there are divergent productivity dynamics between countries. However, the econometric fit is much poorer for shares of GDP than for shares of total employment, which can confound this sort of analysis.

${ }^{4} \mathrm{https}: / /$ unstats.un.org/unsd/snaama/Introduction.asp (UNMNA). GDP data is in current US\$.

5 http://www.ilo.org/ilostat/faces/ilostat-home/home? adf.ctrl-state=97dma1 had 4\& afrLoop=410550119330777\#. This database includes both actual data points and the ILO's modelled estimates of missing values. Sectoral employment data is in general far less available and complete than data on sectoral shares of GDP, which has hampered the analysis of sectoral patterns in terms of employment by limiting country samples. This has also tended to introduce a bias, as employment data is generally especially poor for developing countries, which therefore have tended to be under-represented in this sort of analysis. Although the inclusion of estimated values in the ILOSTAT database could raise doubts around the accuracy of certain values (especially where imputations are undertaken for relatively long gaps in original data), its value lies in the wide country coverage. See also http://www.ilo.org/ilostat-files/Documents/description ECO EN.pdf and http://www.ilo.org/ilostatfiles/Documents/TEM.pdf.

${ }^{6}$ The initial sample includes 181 countries: these are all countries for which data is available on all variables for both 2005 and 2015. We exclude from the sample all countries with a population below one million people. This excludes from the analysis small island nations and other small countries, which may follow atypical development paths that can distort the analysis. We also exclude a further three countries identified as outliers (using Hadi's method, with the significance level for outlier cut-off set at the default value of $p(.05))$.
} 
Econometric results are summarised in Appendix 1. The results satisfy the relevant diagnostic tests. The signs of the estimated coefficients are as expected in both periods, confirming the expected non-linear relationship between GDP per capita and manufacturing share of employment.

It is worth noting that the explanatory power of this basic model is superior in 2005 compared to 2015 , indicating that cross-country differences in GDP per capita explain less of the crosscountry differences in manufacturing share of employment in $2015 .{ }^{7}$

This simple regression yields an estimated turning point for 2015 of approximately $\$ 17000$ (2015 current US\$). This level of GDP per capita corresponds (in this regression) to a $12 \%$ share of manufacturing in total employment. The curve is shown in Figure 7, which also indicates the turning point of the regression - the level of GDP per capita and associated share of manufacturing in total employment at which the latter levels off and subsequently begins to decline.

Figure 7: Estimated relationship between GDP per capita and manufacturing share of employment, 2015

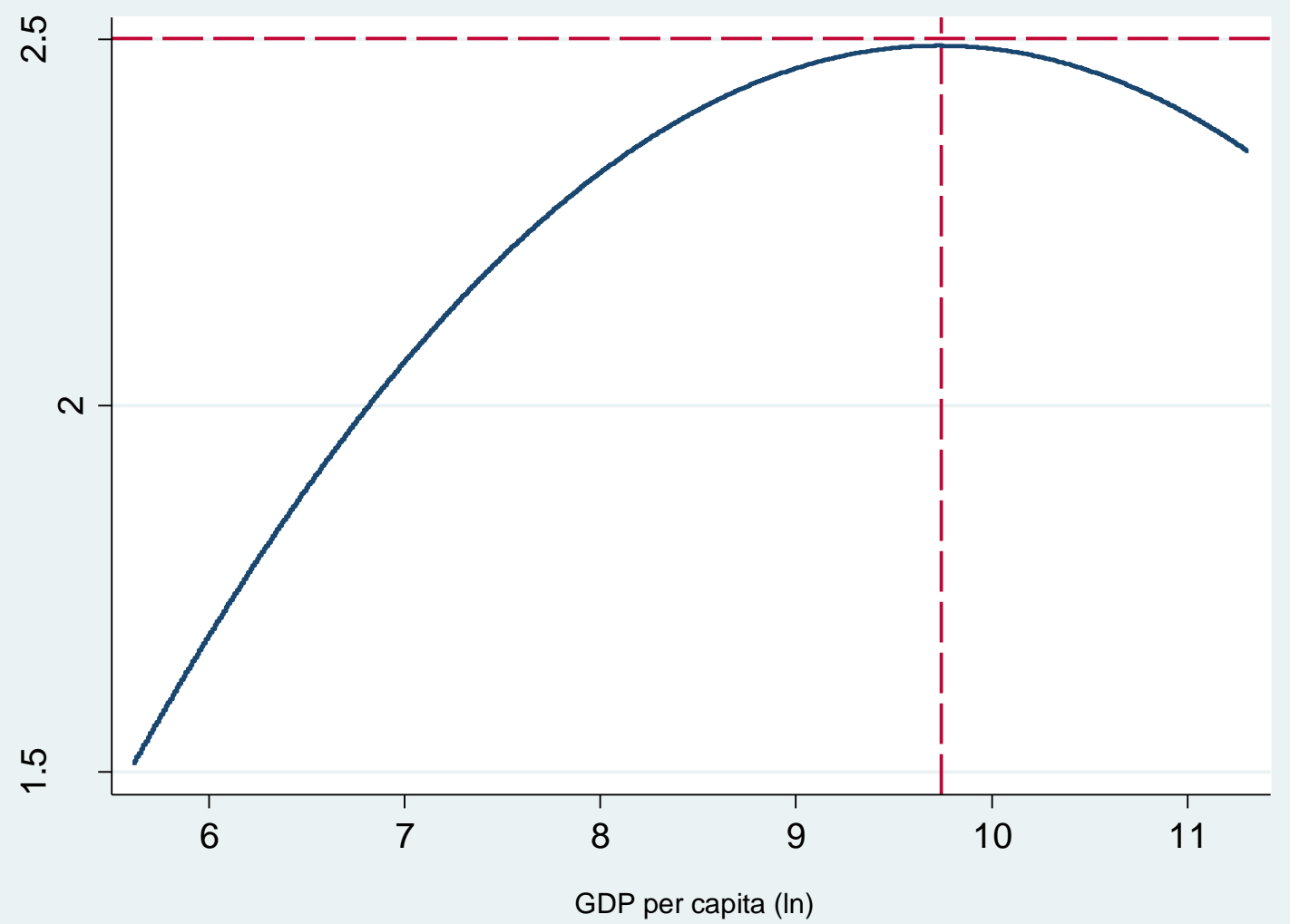

Source: Authors based on UNMNA data

Note: dashed lines indicate the turning point of the relationship.

\footnotetext{
${ }^{7}$ This in itself could be interesting to explore further in a separate paper, especially in terms of which other variables can explain more cross-country differences in manufacturing share of employment over time.
} 
Next, we categorise countries based on two dimensions. Firstly, whether their actual share of manufacturing in total employment in 2015 was higher or lower than would be 'predicted' based on their level of GDP per capita in 2015 and the estimated coefficients from the regression (that is, the sign of the residual term for each country). This dimension gives a sense of which countries may be 'under-industrialised' given their level of GDP per capita. Where this is positive, a country falls above the curve in Figure 7, and conversely where this is negative. Secondly, whether they experienced an increase or decrease in the share of manufacturing in their total employment between 2005 and 2015. This second dimension indicates which countries can be considered (simply on the basis of sectoral employment shares) to have deindustrialised during this period. Taken together, these two dimensions allow us to tentatively classify countries into four broad categories, depicted schematically in the four quadrants of Figure 8.

It must be emphasised that this analysis is exploratory and indicative, rather than definitive. ${ }^{8}$ It is thus only suggestive of which countries might be considered as deindustrialisers, and especially as premature deindustrialisers. A country being classified here as a 'possible premature deindustrialiser' does not necessarily confirm that it is indeed experiencing premature deindustrialisation; similarly, a country may actually be experiencing premature deindustrialisation despite not being classified here as a 'possible premature deindustrialiser'.

Quadrant I includes countries in which the share of manufacturing employment is higher than expected in 2015, and in which this share has grown between 2005 and 2015. Based on this analysis, these countries do not raise a concern in terms of deindustrialisation. Amongst the countries in this quadrant are low- and low-middle-income, fast-industrialising, fast-growing Asian countries such as Cambodia, Indonesia, India, Bangladesh and Myanmar. Countries in Quadrant 4 are also growing their share of manufacturing in total employment, which in 2015 remains below their 'expected' values. Thus, even though these countries might be regarded as 'under-industrialised', they show evidence of industrialising during this decade.

Countries falling in quadrants II and III can be characterised as possible deindustrialisers, in that their share of manufacturing in total employment fell between 2005 and 2015. Yet, in the case of Quadrant II countries, their manufacturing employment share in 2015 still remains above their 'expected' level.

\footnotetext{
${ }^{8}$ Reasons for circumspection in this regard include: that this is just one approach to conceptualising and measuring premature deindustrialisation; the inclusion of estimated values in the ILOSTAT database; limitations of the econometric methodology and specification (including the non-inclusion of explanatory variables other than GDP per capita and its squared term); the narrow range of the predicted values of manufacturing share of total employment; measurement of deindustrialisation only in terms of employment shares and not also shares in GDP; and sensitivity to the specific years used in the analysis. Furthermore, to reach more definitive conclusions, individual country-level analysis would be needed, taking into account country-specific dynamics.
} 


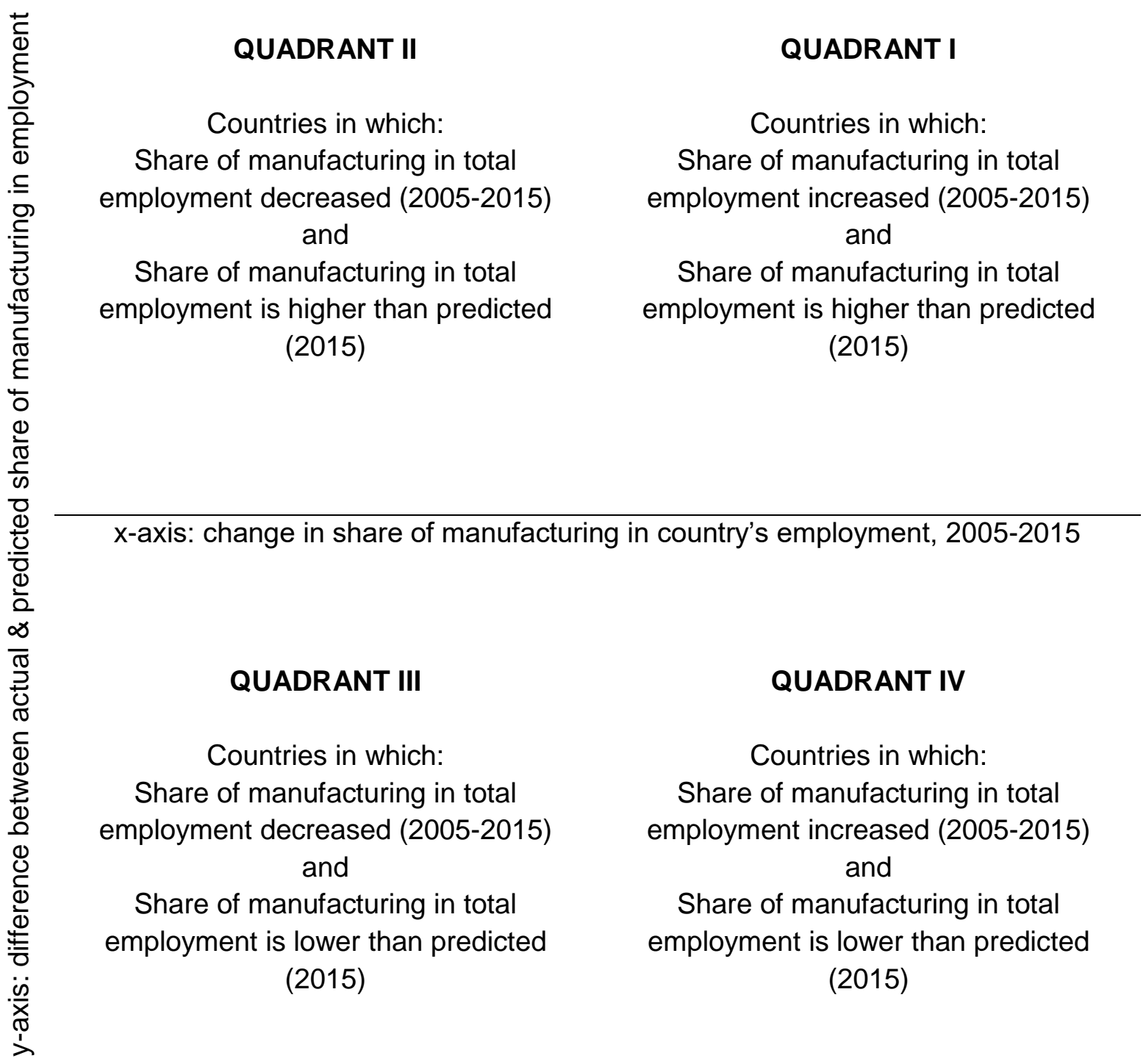

From the standpoint of structural change and concerns around the impact of deindustrialisation on growth, it is the countries falling in Quadrant III that potentially raise more significant concerns. In these countries, the share of manufacturing in employment is lower than would be expected, and they have been further deindustrialising over the past decade. Rather than catching up to their 'expected' level of industrialisation, this group of countries has been falling further behind. Furthermore, some of these countries had a higher than expected level of industrialisation in 2005, but fell below the curve by 2015 .

The distribution of country points between the four quadrants is shown in Figure 9, with the location of South Africa specifically highlighted ('SA'). South Africa falls in Quadrant III - the category of greatest potential concern in terms of deindustrialisation. Between 2005 and 2015, 
the share of manufacturing in South Africa's total employment fell from $13.9 \%$ to $11.2 \%$ (based on the ILOSTAT data). Worth noting is that this is in fact only slightly below the expected value for 2015 based on South Africa's GDP per capita and international patterns of widespread deindustrialisation, that is, South Africa's share is actually close to its predicted value.

The list of countries falling into each of the four categories on the basis of these indicative regression results is shown in Table 1. South Africa is highlighted, along with Brazil, China and Malaysia as the three countries discussed as case studies in section 4. Of particular interest is that these three comparator countries all fall in Quadrant II. Like South Africa, their share of manufacturing in total employment fell between 2005 and 2015. Yet, unlike the case of South Africa, their share of manufacturing in total employment remained higher than predicted in 2015. A key factor in this difference is that these three comparator countries began the period of analysis at relatively higher shares of manufacturing in total employment, for their levels of income per capita, than in the case of South Africa.

Key statistics for South Africa, Brazil, China and Malaysia are shown in Table 2. South Africa had the lowest share of manufacturing in total employment in both 2005 and 2015. Moreover, as discussed, it is the only one among this cohort of countries to have a lower than predicted share of manufacturing in total employment in 2015 (albeit only slightly lower than predicted). Brazil's actual share is only slightly higher than its predicted share, while in China and Malaysia the actual shares are well above predicted shares, indicating the high levels of industrialisation in the latter two countries.

\section{Figure 9: Scatterplot of country results}

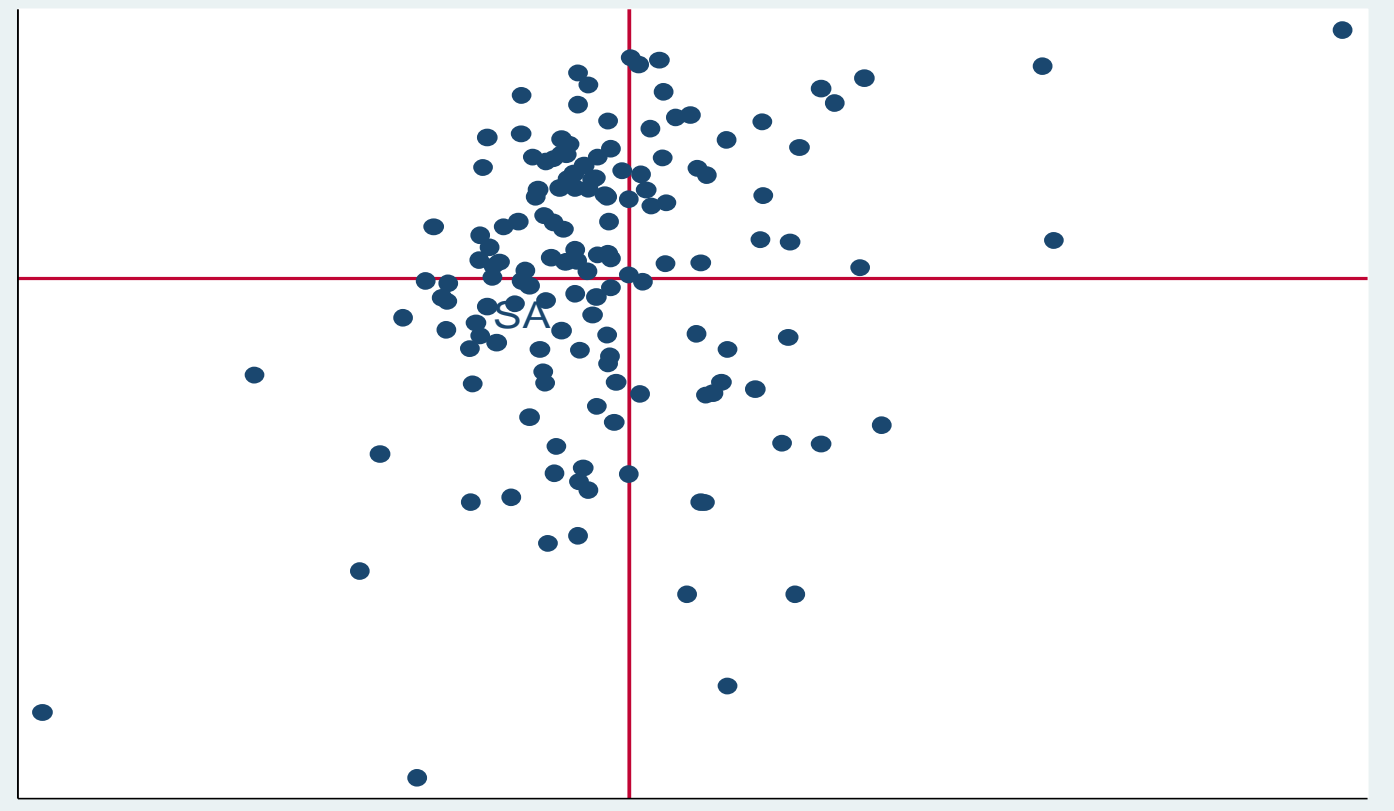

Change in share of manufacturing in country's employment

Note: Each point in this scatterplot indicates a country's change in the share of manufacturing in total employment ( $x$-intercept) and difference between actual and predicted share of manufacturing in its total employment ( $y$-intercept). Quadrants as in Figure 2. 'SA' indicates South Africa. 
Table 1: Cross-country categorisation

\begin{tabular}{|c|c|c|c|}
\hline \multicolumn{2}{|c|}{ QUADRANT II } & \multicolumn{2}{|c|}{ QUADRANT I } \\
\hline Argentina & Korea, Republic of & Algeria & Liberia \\
\hline Austria & Latvia & Bangladesh & Libya \\
\hline Belarus & Lesotho & Benin & Madagascar \\
\hline Belgium & Lithuania & Bosnia and & Myanmar \\
\hline Bolivia & Malawi & Herzegovina & Niger \\
\hline Brazil & Malaysia & Burkina Faso & Pakistan \\
\hline Bulgaria & Mauritius & Cambodia & Paraguay \\
\hline China & Mexico & Central African & Puerto Rico \\
\hline Colombia & Moldova & Republic & Senegal \\
\hline Democratic Republic & Morocco & Congo & Syrian Arab \\
\hline of the Congo & Nicaragua & Czech Republic & Republic \\
\hline Croatia & Occupied & Guinea-Bissau & Thailand \\
\hline Denmark & Palestinian Territory & Honduras & Tunisia \\
\hline Egypt & Poland & India & Turkmenistan \\
\hline El Salvador & Portugal & Indonesia & Uzbekistan \\
\hline Estonia & Romania & Jordan & Venezuela \\
\hline Finland & Russian Federation & Korea, Democratic & Viet Nam \\
\hline France & Serbia & People's & \\
\hline Gambia & Slovakia & Republic of & \\
\hline Germany & Slovenia & & \\
\hline Guatemala & Spain & & \\
\hline Hungary & Sri Lanka & & \\
\hline Iran & Swaziland & & \\
\hline Ireland & Switzerland & & \\
\hline Israel & Togo & & \\
\hline Italy & Turkey & & \\
\hline Japan & Ukraine & & \\
\hline Kenya & & & \\
\hline \multicolumn{2}{|c|}{ QUADRANT III } & \multicolumn{2}{|c|}{ QUADRANT IV } \\
\hline Afghanistan & Kyrgyzstan & Azerbaijan & Mongolia \\
\hline Albania & Mali & Chad & Nigeria \\
\hline Angola & Mauritania & Côte d'Ivoire & Papua New Guinea \\
\hline Armenia & Namibia & Gabon & Rwanda \\
\hline Australia & Netherlands & Guinea & Saudi Arabia \\
\hline Botswana & New Zealand & Haiti & Timor-Leste \\
\hline Burundi & Norway & Kuwait & Uganda \\
\hline Cameroon & Oman & Lao & Yemen \\
\hline Canada & Panama & Lebanon & Zambia \\
\hline Chile & Peru & & \\
\hline Costa Rica & Philippines & & \\
\hline Cuba & Sierra Leone & & \\
\hline Dominican Republic & Singapore & & \\
\hline Ecuador & SOUTH AFRICA & & \\
\hline Eritrea & Sweden & & \\
\hline Ethiopia & Tajikistan & & \\
\hline
\end{tabular}




\begin{tabular}{|ll|l|}
\hline Georgia & Tanzania & \\
Ghana & Trinidad and Tobago & \\
Greece & United Arab & \\
Hong Kong, China & Emirates & \\
Iraq & United Kingdom & \\
Jamaica & United States & \\
Kazakhstan & Uruguay & \\
& Zimbabwe & \\
\hline
\end{tabular}

Note: Countries listed in alphabetical order within each quadrant

Table 2: South Africa and comparator countries

\begin{tabular}{lrrr}
\hline & $\begin{array}{l}\text { Actual share of manuf. } \\
\text { in total employment } \\
2005(\%)\end{array}$ & $\begin{array}{l}\text { Actual share of manuf. } \\
\text { in total employment } \\
2015(\%)\end{array}$ & $\begin{array}{l}\text { Difference btw actual \& } \\
\text { predicted share of } \\
\text { manuf. in total } \\
\text { employment 2015 (\%) }\end{array}$ \\
\hline $\begin{array}{l}\text { South } \\
\text { Africa }\end{array}$ & 13.9 & 11.2 & -0.1 \\
\hline Brazil & 14.2 & 12.5 & 0.7 \\
\hline China & 23.6 & 17.6 & 5.9 \\
\hline Malaysia & 19.8 & 16.5 & 4.6 \\
\hline
\end{tabular}

Next, we further divide Quadrant III countries into those that might be regarded as possible premature deindustrialisers. We identify which of these countries has GDP per capita in 2015 below the turning point. That is, we classify possible premature deindustrialisers for 2015 as those countries in which: (1) the share of manufacturing in total employment fell between 2005 and 2015; (2) the share of manufacturing in total employment in 2015 was less than would be expected based on their GDP per capita (i.e. they fell below the curve shown in Figure 7); and (3) their GDP per capita in 2015 was below the level of GDP per capita associated with the turning point in the relationship based on the pattern found across countries (i.e. they fell to the left of the turning point shown in Figure 7). As such, this set of countries excludes those in Quadrant III with levels of GDP per capita above the income turning point (i.e. advanced economies that are deindustrialising). This part of the analysis thus introduces a third dimension (to the left or right of the income turning point), in addition to the two dimensions portrayed in the earlier parts of this analysis), to identify the (potential) premature aspect of the deindustrialisation experiences internationally.

These 33 'possible premature deindustrialisers' are listed in Table 3, which also shows information on countries' income and regional group classifications. Of this group, eight can be classified as low income, seven as lower-middle income, 15 as upper-middle income, and three as high income. In terms of regional distribution, almost half (14) are in sub-Saharan Africa. This is consistent with what Tregenna (2016) has described as a phenomenon of 'preindustrialisation deindustrialisation' in some (especially low-income) sub-Saharan African countries. Another nine are from Latin America and the Caribbean, six from Europe and Central Asia, two from the Middle East and North Africa, one from Southern Asia, and one is from East Asia and the Pacific. As discussed earlier, South Africa is amongst this Quadrant III group of possible premature deindustrialisers. 
Table 3: Possible premature deindustrialisers, 2005-2015

\begin{tabular}{|c|c|c|}
\hline Country & Income group & Region \\
\hline Afghanistan & Low & South Asia \\
\hline Albania & Upper middle & Europe and Central Asia \\
\hline Angola & Upper middle & Sub-Saharan Africa \\
\hline Armenia & Lower middle & Europe and Central Asia \\
\hline Botswana & Upper middle & Sub-Saharan Africa \\
\hline Burundi & Low & Sub-Saharan Africa \\
\hline Cameroon & Lower middle & Sub-Saharan Africa \\
\hline Chile & High & $\begin{array}{l}\text { Latin America and the } \\
\text { Caribbean }\end{array}$ \\
\hline Costa Rica & Upper middle & $\begin{array}{l}\text { Latin America and the } \\
\text { Caribbean }\end{array}$ \\
\hline Cuba & Upper middle & $\begin{array}{l}\text { Latin America and the } \\
\text { Caribbean }\end{array}$ \\
\hline Dominican Republic & Upper middle & $\begin{array}{l}\text { Latin America and the } \\
\text { Caribbean }\end{array}$ \\
\hline Ecuador & Upper middle & $\begin{array}{l}\text { Latin America and the } \\
\text { Caribbean }\end{array}$ \\
\hline Eritrea & Low & Sub-Saharan Africa \\
\hline Ethiopia & Low & Sub-Saharan Africa \\
\hline Georgia & Upper middle & Europe and Central Asia \\
\hline Ghana & Lower middle & Sub-Saharan Africa \\
\hline Iraq & Upper middle & $\begin{array}{l}\text { Middle East and North } \\
\text { Africa }\end{array}$ \\
\hline Jamaica & Upper middle & $\begin{array}{l}\text { Latin America and the } \\
\text { Caribbean }\end{array}$ \\
\hline Kazakhstan & Upper middle & Europe and Central Asia \\
\hline Kyrgyzstan & Lower middle & Europe and Central Asia \\
\hline Mali & Low & Sub-Saharan Africa \\
\hline Mauritania & Lower middle & Sub-Saharan Africa \\
\hline Namibia & Upper middle & Sub-Saharan Africa \\
\hline Oman & High & $\begin{array}{l}\text { Middle East and North } \\
\text { Africa }\end{array}$ \\
\hline Panama & Upper middle & $\begin{array}{l}\text { Latin America and the } \\
\text { Caribbean }\end{array}$ \\
\hline Peru & Upper middle & $\begin{array}{l}\text { Latin America and the } \\
\text { Caribbean }\end{array}$ \\
\hline Philippines & Lower middle & East Asia and Pacific \\
\hline Sierra Leone & Low & Sub-Saharan Africa \\
\hline SOUTH AFRICA & UPPER MIDDLE & SUB-SAHARAN AFRICA \\
\hline Tajikistan & Lower middle & Europe and Central Asia \\
\hline Tanzania & Low & Sub-Saharan Africa \\
\hline Uruguay & High & $\begin{array}{l}\text { Latin America and the } \\
\text { Caribbean }\end{array}$ \\
\hline Zimbabwe & Low & Sub-Saharan Africa \\
\hline
\end{tabular}

Note: Countries listed in alphabetical order.

Income and regional group classifications based on World Bank classification, income groups use 2015 classification (see https://datahelpdesk.worldbank.org/knowledgebase/articles/906519-worldbank-country-and-lending-groups) 


\section{Escaping from the Premature Deindustrialisation Trap: Industrial Policies for Middle-income Countries}

This section offers an industrial policy framework and an in-depth comparative review of three country case studies. For each of these, specific initiatives which have helped these countries in dealing with the specific industrialisation challenges highlighted above are also presented. The analysis shows what policies are relatively successful in supporting (re)industrialisation and overcoming the premature deindustrialisation trap. By describing key policy instruments (the 'what' and 'how' industrial policy) and the ways in which different countries have designed and implemented them in practice, this sections engages with a broad range of policy instruments focusing on five different policy areas.

\subsection{An industrial policy framework for middle-income countries: Instruments and governance challenges}

Industrial policymaking is a complex process, as it entails the management of multiple interactive measures and instruments (Andreoni, 2016). In his account of the lessons learned from East Asia, Stiglitz (1996) emphasises how these countries can only be understood by analysing their 'packages of interactive measures' in terms of which companies were exposed to different types of internal and external competitive pressures. This policy option is also stressed by Chang (2011:100) when he writes,

In East Asia, free trade, export promotion (which is, of course, not free trade), and infant industry protection were organically integrated, both in cross-section terms (so there always will be some industries subject to each category of policy, sometimes more than one at the same time) and over time (so, the same industry may be subject to more than one of the three over time).

Finally, in the context of Scandinavian countries, Landesmann (1992:242) stresses how these countries adopted an "interesting mix of both defensive and constructive policies".

Table 4 below provides a list of industrial policy instruments, organised around five key policy areas. These are:

i. Production, technological and organisational capabilities building

ii. Innovation and technological change

iii. GVC integration, local production system (LPS) development and industrial restructuring

iv. Demand and trade

v. Industrial finance

These areas have been selected as they match the critical challenges that countries in the middle-income status present, which might also lead to their premature deindustrialisation. A number of policy instruments are effective tools in addressing more than one policy area. The table also shows the extent to which the selected country cases have adopted these instruments, as well as other successful middle-income country cases. 
Table 4: An industrial policy toolbox for middle-income countries

\begin{tabular}{|c|c|c|c|c|c|c|c|}
\hline AREAS & \multicolumn{2}{|l|}{$\begin{array}{l}\text { PREMATURE DEINDUSTRIALISATION AND MIDDLE } \\
\text { INCOME TRAP CHALLLENGES }\end{array}$} & POLICY INSTRUMENTS & Brazil & \multirow[t]{2}{*}{ China } & \multirow[t]{2}{*}{ Malaysia } & \multirow[t]{2}{*}{$\begin{array}{c}\text { Other } \\
\text { country cases }\end{array}$} \\
\hline & $\begin{array}{l}\text { PRODUCTION, TECHNOLOGICAL AND } \\
1 \text { ORGANISATIONAL CAPABILITIES BUILDING }\end{array}$ & 1.1 & SKILLS POLICY (TVET) & $\mathrm{x}$ & & & \\
\hline & & 1.2 & $\begin{array}{l}\text { R\&D\&M INTERMEDIATE INSTITUTIONS AND } \\
\text { EXTENSION SERVICES }\end{array}$ & $x x x$ & $x x x$ & $x x x$ & $\begin{array}{l}\text { South Korea, } \\
\text { Taiwan }\end{array}$ \\
\hline & & $1.3 \& 2.1$ & MATCHIG GRANTS FOR INVESTMENTS & & $x x x$ & $\mathrm{xx}$ & India \\
\hline \multirow{2}{*}{\multicolumn{2}{|c|}{2 INNOVATION AND TECHNOLOGICAL CHANGE }} & 2.2 & PPP RESEARCH CONSORTIA WITH UNIVERSITIES & $x x$ & $x x$ & $x x$ & South Korea \\
\hline & & 2.3 & JOINT VENTURES WITH TNC & $x$ & $x x x$ & $x x x$ & Vietnam \\
\hline \multicolumn{2}{|r|}{$\begin{array}{l}\text { GVC INTEGRATION, LPS DEVELOPMENT AND } \\
3 \text { INDUSTRIAL RESTRUCTURING }\end{array}$} & 3.1 & $\begin{array}{l}\text { MERGERS AND ACQUISITION AND RECESSION } \\
\text { CARTELS }\end{array}$ & $\mathrm{x}$ & $x x x$ & $\mathrm{x}$ & South Korea \\
\hline & & 3.2 & COMPETITION POLICY & & $x$ & & \\
\hline & & 3.3 & FDI INCENTIVES & $\mathrm{x}$ & $x x x$ & $x x x$ & Vietnam \\
\hline & & 3.4 & LOCAL CONTENT POLICY & $x x$ & $x x x$ & $x x x$ & Vietnam \\
\hline & & 3.5 & SMES INCENTIVES & $\mathrm{x}$ & $x x x$ & $x x x$ & India \\
\hline & & 3.6 & CLUSTER POLICY & $x$ & $x x x$ & $\mathrm{xx}$ & India \\
\hline & & $3.7 \& 4.1$ & $\begin{array}{l}\text { SPECIAL ECONOMIC ZONES / EXPORT PROMOTION } \\
\text { ZONES }\end{array}$ & $\mathrm{x}$ & $x x x$ & $\mathrm{xxx}$ & Indonesia \\
\hline \multicolumn{2}{|r|}{4 DEMAND AND TRADE } & 4.1 & $\begin{array}{l}\text { EXTERNAL DEMAND: TRADE POLICY / REGIONAL } \\
\text { VCs }\end{array}$ & $\mathrm{x}$ & $x x x$ & $x x$ & \\
\hline & & 4.2 & EXTERNAL DEMAND: EXPORT CARTELS & & $x x$ & $x$ & \\
\hline & & 4.3 & INTERNAL DEMAND: PUBLIC PROCUREMENT & $x x$ & $x x x$ & $\mathrm{x}$ & \\
\hline & & $4.4 \& 5.1$ & EXPORT ORIENTED: EXPORT FINANCE SERVICES & $x x$ & $x x x$ & $x x$ & Thailand \\
\hline \multicolumn{2}{|r|}{5 INDUSTRIAL FINANCE } & 5.2 & LONG TERM: DEVELOPMENT BANKS & $x x x$ & $x x x$ & $\mathrm{x}$ & India \\
\hline & & 5.3 & $\begin{array}{l}\text { SMALL SIZE: HYBRID/BLENDED } \\
\text { FINANCE/GRANT/PROCUREMENT }\end{array}$ & $x$ & $x x x$ & $x x$ & \\
\hline & & 5.4 & PUBLIC: INVESTMENT POLICY & $x x$ & $x x x$ & $x x$ & \\
\hline
\end{tabular}

Source: Authors 
As discussed in Andreoni (2016), the identification of a mix of policy instruments is only the first step. Indeed, these instruments must be aligned, coordinated and synchronised over time. Policy matrixes are useful tools in addressing the challenges faced by industrial policy makers in aligning and coordinating packages of interactive measures across different policy targets and areas. First, a policy matrix allows for mapping out the different policy instruments a given government is implementing. In doing so, policy matrixes provide a good basis for reflecting on the degree of targeting of each policy instrument and how it is governed. Secondly, the policy matrix helps in identifying the potential interactions linking the different policy instruments adopted by different ministries, departments and agencies (MDAs) and implemented across different policy areas. Finally, by revealing the presence of policy interactions within the overall policy package, it is possible through the policy matrix to identify potential policy misalignment or trade-offs that would remain unnoticed otherwise. These misalignments might also be related to a lack of coordination or duplication among MDAs, as well as the fact that the instruments adopted by one government are not synchronised with those left by previous governments.

The policy matrix proposed by Andreoni (2016) considers three main axes:

\section{i. Industrial policy governance model}

This axis defines the extent to which policies are implemented by MDAs at the regional/state level or at the national/federal level. Of course, as in the case of regional agreements such as the East Africa Community, there is also a supranational level of policy-making.

\section{ii. Industrial policy targets and areas}

Each industrial policy instrument targets a specific set of goals, which can be clustered in various policy areas. For example, R\&D credit, standardisation policy and public technology intermediaries are all instruments/measures/institutions targeting the 'Innovation and Technology Infrastructure' policy area. While industrial policy generally relies on supply-side instruments, there are also clusters of policy areas, including demand-side type of instruments such as procurement policy and external market development policies.

\section{iii. Industrial policy levels of intervention.}

Each industrial policy instrument can be more or less selective. Some policy instruments are tailored as sector-specific measures, and can also target specific firms within those sectors (SMEs in the food supply chain, for example). Then there are policies that are focused on the manufacturing system as a whole, in particular those targeting export promotion or the development of technology platforms that are critical for manufacturing development (e.g. capabilities in machine tools). Some industrial policy instruments can focus more openly on cross-sectoral targets in the industrial system, for example, those targeting better integration between the agriculture and manufacturing industries. Finally, there are policies that are more macroeconomic in nature, such as interest rate and exchange rate policies. Despite the fact that they will affect the overall economy, this does not mean that they will affect all sectors of the economy in the same way. A certain interest rate policy will affect sectors with different degrees of capital intensity differently. 
Figure 10: Policy matrix for industrial policy package analysis

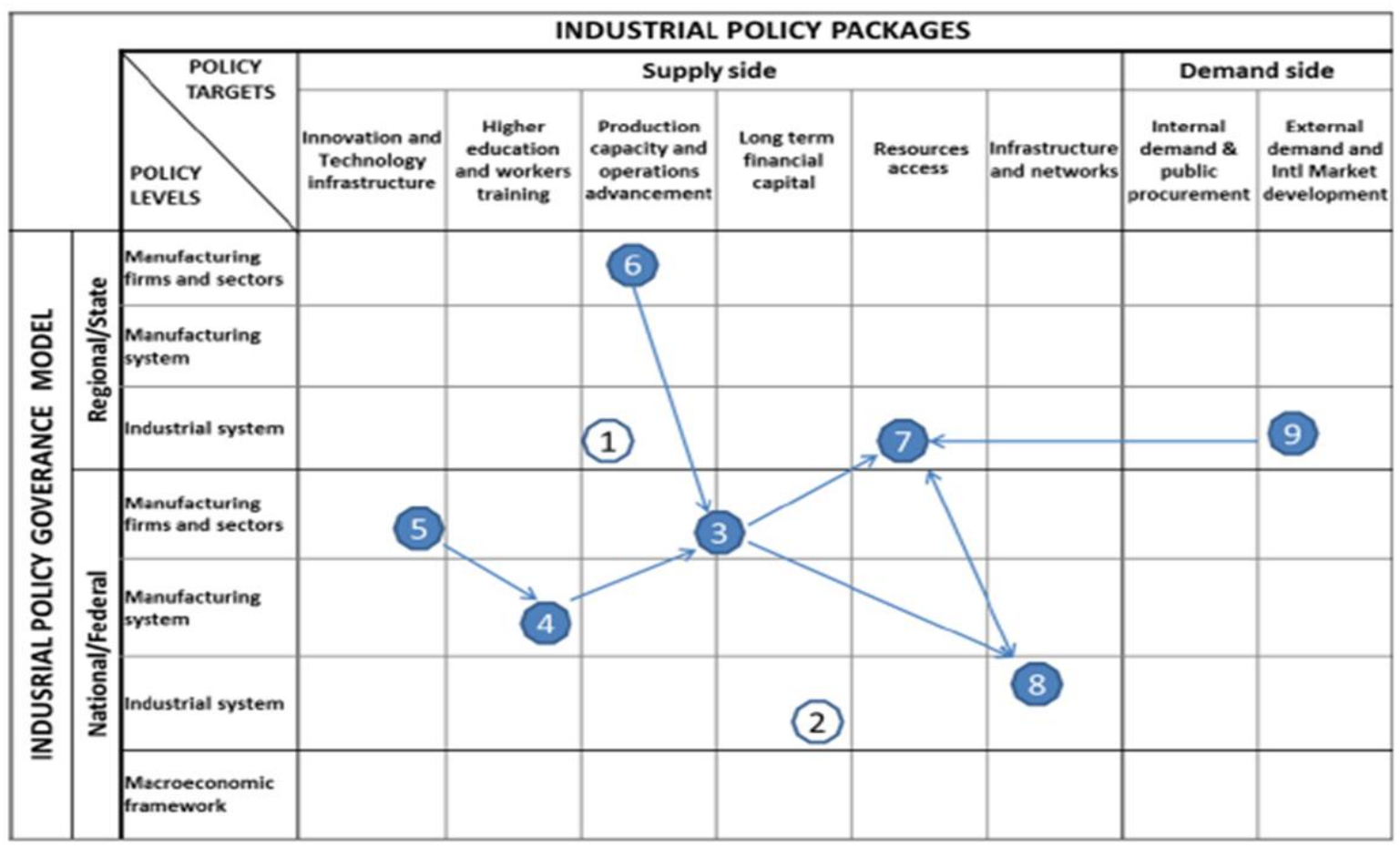

Source: Andreoni (2016)

Countries can adopt different packages of industrial policy measures and can coordinate different policy instruments, either to have a combined effect on the same target or to manage potential trade-offs among different goals. For example, education policies can be aligned with labour market reforms to improve workers' conditions. Technology policies can also be aligned with trade policies or public procurement measures supporting domestic industrial sector development. Potential trade-offs arising between economic growth and increasing pressure on natural resources can be counterbalanced by aligning sectoral policies and technology policy, in particular the development and deployment of green technologies over time.

In sum, the effectiveness of a single policy measure depends on its linkages with other policy measures acting upon the same companies, sectors and specific institutions. This implies that the policy effectiveness of a certain instrument might be improved by both/either using the instruments more effectively and/or by changing or introducing other complementary instruments. The combined effect of different policy instruments tends to be different from the one that the government can achieve by the independent implementation of the same policy measures in time.

The governance of industrial policy as packages of interactive measures presents several challenges, which are particularly severe in middle-income countries like South Africa. Industrial policy governance challenges are due to multiple factors and dynamics that operate and unfold in three areas: (i) the public sector, (ii) the interaction between public MDAs and private sector constituencies, and (iii) the private sector among different powerful groups and interests. 


\section{Governance challenges in the public sector}

Within the public sector, the government is articulated in different MDAs operating at both the national and sub-national levels. A number of these institutions are settled to perform critical industrial policy functions, allocating rents in the form of subsidies, licensees, tax exemptions etc. However, in some countries, public department and agencies have been often proliferating as a result of political processes of consensus and clientelist network building. This means that, despite their official mandate, these institutions do not de facto perform any specific industrial development and productive capabilities-building function. In some extreme cases, they are not simply ineffective, but they can actually become rigidities in the government institutional structure and strong forces resisting any change.

Another critical governance challenge in the public sector is related to the fact that the mandate of some government institutions is often unclear, and duplication across MDAs is very common. As a result, when policymakers attempt to design instruments for productive capacities building, they often face a highly dysfunctional and rigid institutional structure. This is particularly the case when the implementation of certain policy instruments cannot be prescinded from inter-MDA coordination. The reason why reforming these institutional and governance structures is particularly difficult is related to the fact that MDAs are often focused on preserving their policy space and resources, thus they are not willing to restructure institutions or reduce duplications. In particular, MDAs compete for protecting and eventually increasing the resources they have been allocated from the central government budget.

\section{Governance challenges and political economy dynamics in the interaction between public and private sectors}

The relationship between the government and the private sector matters. Experience shows the importance of continuous dialogue and exchange of information between the two if the policies are going to be well informed and relevant. However, it is also important that the government does not become beholden to particular industrial interests and thus to avoid the danger of 'capture'. Peter Evans (1995) has captured this point with the notion of 'embedded autonomy', which means that the government needs to have roots in society ('embeddedness'), but also has to have its own will and power ('autonomy') in order to be effective in its intervention.

Historically, countries with a strong landlord class or a strong financial capitalist class have found it difficult to implement good industrial policy, as those classes want policies that could be detrimental to the development of productive capacities. One such prominent example is the US landlords in the South, who, up until the Civil War, constantly exerting pressure for free trade, despite the fact that it would have deterred the development of the country's manufacturing sector. In the more recent period, we have seen the strong financial capitalist classes of the UK and Brazil wanting policies that lead to overvalued exchange rates, thereby destroying large swathes of their export-oriented manufacturing industries.

In understanding the relationship between the government and the private sector, it is critical to start from assessing the distribution of organisational power in both the public and private sectors - thus, the countries' "political settlement" (Khan, 2010) - and the relationship between powerful organisations (including elites and intermediate groups) operating in both (and at the 
interface between) the public and private sectors. Khan (2010:4) defines the political settlement as "a combination of power and institutions that is mutually compatible and also sustainable in terms of economic and political viability". The analysis of a country's political settlement allows for the assessment of the feasibility of certain policy intervention and, thus, the extent to which a certain policy instrument can be implemented and enforced in a given political settlement.

\section{Governance challenges and political economy dynamics in the private sector}

The private sector in LDCs is characterised by a limited number of industrialists capable of investing in a competitive market setting and a plurality of big players involved in trading activities, construction and services (Andreoni, 2018; Khan et al., 2016). The lack of mediumsized companies and the dominance of micro- and small enterprises, often operating informally, complete the private sector scenario in LDCs. In such a business environment, power is concentrated mainly in the hands of big players in the importing, construction and service industries. These players tend to have interest that conflict with those of industrialists and other SMEs, for example with respect to competition for the internal market.

Private sector investment in productive capacities building is particularly difficult in developing countries, as the distribution of power and the incentive structure discourage productive investments. Given the lack of productive capacities, importing produce from other countries tends to be cheaper and less risky. Moreover, investments in productive activities is perceived to be riskier than operating in the construction or services industries. As a result, financial capital and interest rates mostly favour the latter sectors, and investments in productive activities remain limited in scale and scope. Finally, given the lack of medium-sized companies, the few big industrialists are able to squeeze their local supply chains, which remain disarticulated and incapable of reaching an efficient scale.

Industrial policy for productive capacities building can play a central role in transforming the private sector and moving towards a more balanced distribution of power. By mobilising resources towards productive forces in the private sector, and creating incentives for the building up of the local production system, industrial policy can make productive investments feasible and profitable. However, to be effective, the design, implementation and enforcement of industrial policy must take into consideration what the specific resources and incentives are that different players along different sectoral value chains will need to become more productive. The governance of industrial policy at the sectoral value chain level often requires close coordination and strategic alliances between productive forces in both the public and private sectors. From the perspective of government, industrial policy must have a tangible political dividend. The private sector must perceive the investment to be feasible and as a viable alternative way of making profit.

\subsection{Case study 1: Brazil and the industrialisation of agriculture}

Brazil underwent three major phases of industrial development and policy.

The first wave lasted until 1980 and was characterised by extensive state-indicative planning in the areas of sectoral development (e.g. steel, petrochemical and renewable fuels policies) and trade protection (e.g. ad valorem tariffs and law of similarities). Industrial policy was aimed 
mainly at creating new industrial sectors, changing the prevalent pattern of specialisation in primary commodities and promoting technology-intensive activities. The main industrial policy strategy of this period was set up in the 1950s and consisted of the introduction of a protectionist regime based on ad valorem tariffs. The federal government had the discretionary power to control the level and types of imports. The Law of Similarities (Lei do Similar Nacional) stated that a product could only be imported if it could be proved that a similar product was not produced in Brazil. These measures were intensified during the period from 1960 to 1980 within an import substitution industrialisation (ISI) strategy.

Despite the controversial results of the ISI strategy, the Brazilian government also played a critical role in technological upgrading during this first phase (e.g. research in agrotechnologies within Embrapa and aircraft technologies deployed in Embraer). A number of state-owned enterprises in strategic manufacturing sectors were developed, such as Petrobras (1953), Usiminas (1956), Eletrobras (1962) and Embraer (1969), and a public development bank (BNDES) was established in 1952. A few years before, in 1942, the biggest Brazilian mining company, Vale do Rio Doce, was created as a state-owned enterprise (SOE) to operate mainly in the extraction of iron ore, the dominant mineral in Brazil.

Some of these companies and institutions are today the pillars of the Brazilian industrial, financial and agricultural system. For example, the Brazilian Development Bank (BNDES) is the main provider of long-term finance in the country and one of the biggest in the world measured by assets, equity and disbursement (Ferraz et al., 2013). Embrapa is the largest research and development $(R \& D)$ agency in Latin America.

During the 1980s and 1990s, the debt crisis forced the Brazilian government to reduce its industrial policy interventions in favour of Structural Adjustment Policies and macroeconomic stabilisation. Structural adjustment policies were initially directed at trade liberalisation and the privatisation of public enterprises, while from the mid-1990s they increasingly focused on macroeconomic stabilisation (the 'Real Plan'). During this second phase, the total number of special trade regimes and tariff rates were reduced and a significant number of public enterprises were privatised (for example, Vale do Rio Doce).

The 2000s signalled the return of selective (sector-specific) industrial policies in Brazil. In November 2003, the first Lula government announced the Guidelines for an Industrial, Technology and Foreign Trade Policy (PITCE) aimed at increasing industrial competitiveness by boosting technological development in key sectors (semi-conductors, software, pharmaceuticals and medicines, and capital goods), thus promoting the export of higher valueadded products. This industrial policy was also complemented by technology policies and regulations aimed at advancing Brazil's science and technology bases in biotechnology, nanotechnology and biomass/renewable energies. These technologies were considered critical to develop the oil and gas, agriculture, and pharmaceutical sectors.

The implementation of this package of industrial and technology policies relied on specific financing programmes, such as Profarma (pharmaceutical) and Prosoft (software), as well as the integration of over 15 sectoral funds. In this way, the government managed to "align them [the funds] to government policies, eliminating duplication and scattershot initiatives" (ABDI 2006:20), as well as divert resources towards applied industrial research (including pre- 
competitive research), prototyping, and the commercialisation of innovation, problem-driven basic research, Intellectual Property Rights (IPR) and Public-Private Partnerships (PPPs).

The PITCE was followed by an ambitious industrial policy package, called the Productive Development Policy (2008-2011), and the Plano Brazil Maior was launched in 2011.

The Productive Development Policy (PDP) was structured around four challenges: First, sustaining the expansionary cycle by maintaining the rate of growth in Gross Fixed Capital Formation (GFCF) ahead of the GDP; second, upgrading and diversifying the export basket; third, fostering technological investment and innovation; and fourth and finally, restructuring the industrial system and supporting SMEs, as well national industrial drivers. The PDP is a complex industrial policy package aligned with specific macro-targets and comprising 425 policy measures (organised into 34 programmes, including both 'sectoral' and 'systemic' actions). The sectoral actions expand PITCE's targets along three main lines: 'Mobilization Programmes in Strategic Areas', 'Programmes to Strengthen Competitiveness', and 'Programmes to Consolidate and Expand Leadership' (Kupfer et al., 2013). The management and implementation of this complex package of interventions has proven extremely challenging, and in some cases the lack of focus has negatively impacted upon the intended results.

The Brasil Maior Plan (PBM) was launched in 2011, and signalled the last systematic attempt of the Brazilian government in recent history at implementing industrial policy. The 'strategic map' underpinning the PBM identifies four interdependent guiding principles/objectives. The first is strengthening critical competencies in terms of production capacity, corporate R\&D and industrial skills; second is enhancing value chains by structural upgrading and re-organisation of production systems. Third, the PBM sought to expand both domestic and foreign markets beyond specialisation in primary goods, and finally also sought to expand the development of social and environmental sustainability. A number of different policy measures have been adopted to implement these guidelines. For example, the PBM strengthens production chains, diversifying/upgrading exports through tax relief, trade remedies (e.g. anti-dumping measures), financing, and loan guarantees for exporters (especially for SMEs). More shortterm measures have been integrated, as well as systemic and long-term measures like infrastructure development and demand-side interventions (e.g. the government procurement policy was updated).

Over the years, Brazil's industrial policy achieved important results in two major sectors, namely mining and agrobusiness. The models followed are very different, as the first one relied on a successful case of privatisation with a company - Vale - that managed to develop several linkages in the economy and boost the competitiveness of local production systems. The second one mainly centred on state-led long-term investments in the R\&D\&M of intermediate institutions.

Mining is a strategic sector in the Brazilian economy, employing 2.2 million people and contributing significantly to the country's export performance (minerals constituted $33 \%$ of total export in 2010) (ICMM, 2013). Iron ore companies also account for $65 \%$ of total tax revenues (Falco et al., 2011). The Brazilian Mining Royalty (CFEM) is paid to the federal government, which then distributes the revenues at state (12\% of the amount) and municipality (65\% of the 
amount) levels ${ }^{9}$. Vale is the second biggest company in Brazil and the world's fifth largest mining firm, with annual revenues of US $\$ 33.2$ billion. It is the leading mining firm, with $52.3 \%$ of domestic mineral production, and it operates in 13 different states across the country and in 37 countries around the world (Figueiredo \& Piana, 2016). Vale played a key role in the regional development of the local production system. The company also established the Vale Technology Institute (VTI), which is the largest public-private research partnership ever achieved in Brazil (Falco et al., 2011). Through this institute, Vale is actively involved in different innovation development projects, public-private collaborations and supply chain initiatives. They set up and patented, in Brazil and in the United States, the first fully dry iron ore-tailing process, which was also adopted in the S11D mine. Previously, the flotation system that was used to raise the content of fine iron ore required an average of 1000 litres of water per ton. This is a major innovation for mining, which is ranked second among waterconsumption industries (Mining News, 2016).

\section{Intermediate institutions: The Embrapa case study}

Over the last thirty years, Brazil has been among the most active countries in terms of its use of policies designed to expand natural resource-processing industries and food production. The results of these transformative policies are reflected in the remarkable results Brazil has achieved in manufacturing its agrarian change. Brazil is today among the top producers and exporters of orange juice, sugar, coffee, soya beans, beef, pork and chicken, as well as having caught up with the traditional big five grain exporters (USA, Canada, Australia, Argentina and the EU). At the centre of the transformative policy package implemented in Brazil is a network of intermediate institutes - e.g. Embrapa, which have fostered technological change, diversification and upgrading in agriculture and farming.

Embrapa was founded in 1972 as a response to the main weaknesses of DNPEA (the National Agricultural Research and Experiment Department). These included "researchers' lack of awareness of the basic needs of agriculture and the lack of intradepartmental and external interaction among researchers, extension workers, and farmers (which had led to instances of unproductive duplication of research efforts)". Other weaknesses involved "the lack of incentives for researchers (particularly indicated by low salaries), the low level of postgraduate training (12 percent [of] the scientific staff at the time), and finally the insufficient, and often irregular financial resources available" (Beintema et al., 2001:16). Embrapa took over DNPEA's extensive network of research institutes, covering the main agricultural commodities and regions, experiment stations and existing projects. Agricultural extension services were outside Embrapa's area of intervention and were assigned to another agency, Embrater, which operated until 1991.

During its first decades, Embrapa created a network of national commodity centres and regional centres that focused on major cropping and animal production systems, as well as on eco-regional and national themes. It also increased its internal capabilities by signing partnerships with American universities such as Purdue and Wisconsin, which allowed Embrapa's staff to receive postgraduate training. In 1993, the establishment of the Embrapa

\footnotetext{
${ }^{9} \mathrm{~A}$ recent reform (2017) changed the royalty system, increasing the amount of royalties to be paid by $2 \%, 3 \%$ or $4 \%$ depending on the company and the mineral. In addition, the basis of the calculation goes from the net revenue to the company's gross revenues (from the second half of 2017).
} 
Planning System (SEP) for the first time introduced a systems approach to R\&D planning. This allowed a redefinition and reintegration of the centre's mission, objectives, programmes, human resources, infrastructural needs and priorities.

From the late 1980s, agricultural research became even more cross-pollinated by research in advanced manufacturing. A good example of this is the satellite monitoring services for the acquisition and processing of remote sensor images and field data. The Satellite Monitoring Centre was created in 1989 in an area of $20000 \mathrm{~m}^{2}$ in Campinas (Sao Paulo state), assigned by the Brazilian Army to Embrapa for the development of a special unit focused on territorial management systems and electronic networks for modern agriculture.

Throughout the 1990s, Embrapa was involved in a wide range of activities related to agricultural research and technology including plant breeding, pest management, food safety, satellite monitoring, sustainable agricultural development, and hunger relief. Soybean breeding and pest management activities are headquartered at the Embrapa facility in Londrina in the state of Paraná, but crop research activities are carried out at locations around the country to develop crops and varieties that are suited for local conditions (Matthey et al., 2004:10).

The trend started in the 1990s continued during the next decade, in particular in 2005 and 2006, when Embrapa made a serious effort to improve and renovate its infrastructure. Included among these investments, at the interface between agriculture, biotechnologies and advanced manufacturing, were:

i) Facilities for quality improvement in the meat production chain;

ii) An aquaculture laboratory prioritising water quality control, fish feeding and health;

iii) A new Oenology Laboratory to boost wine production in the North-eastern SemiArid Region;

iv) The construction of one of the world's first National Agribusiness Nanotechnology Laboratories focused on the development of sensors and biosensors for food quality control, certification and traceability. The Laboratory was also dedicated to the synthesis of new materials, such as polymers and nanostructured materials or thin films and surface-to-manufacture smart packages.

v) The building on six new walk-in freezers to increase the storage and preservation capacity of the Embrapa Germplasm Bank (from 120 to 240 thousand seeds).

Probably the most recent remarkable achievement of Embrapa has been the claiming of the Cerrado (the Brazilian savannah) for modern agriculture. It introduced "new varieties, cultural practices, zoning, tillage, biological fixation of nitrogen, development of livestock for both meat and milk, vegetables, fruit, irrigation and knowledge of the Cerrado natural resource basis" (Alves, 2010:70). Embrapa's technological efforts were also reinforced by government investment, which established new universities and postgraduate courses in all states of the Cerrado region.

Today, Embrapa includes 47 research centres (15 National 'Thematic' Centers, 16 National 'Commodity' Centers and 16 Regional 'Resource' Centers) throughout the country. It hosts 9284 employees and has an annual budget of over US\$1 billion. Similar to Fraunhofers in Germany, Embrapa plays a critical intermediary role between agricultural and manufacturing $R \& D$, education, markets, and in-farm agricultural production. It also bridges and transfers 
knowledge, technical solutions and innovations across different sectors, thus facilitating various forms of inter-sectoral learning (Andreoni, 2014; Andreoni \& Chang, 2014). According to information provided by the Brazilian government, Embrapa has generated and recommended more than nine thousand technologies for Brazilian farmers since its inception in 1973.

\subsection{Case study 2: China and the manufacturing of an innovation economy}

During the final two decades of the last century, China prepared its gradual transition to a market economy. Industrial policies were an integral part of China's strategic five-year planning. Many initiatives and policy measures, especially in the early period, were inspired by the successful experiences of Japan and Korea. While the Sixth Plan (1981-1985) marked a more distinctive outward-oriented approach, focusing on importing technologies and developing endogenous capabilities, the government used the Seventh Plan (1986-1990) to establish an Industrial Policy Department under the State Planning Commission. In March 1989, the concept of industrial policy was explicitly mentioned for the first time in an official document (the State Council's paper, Decision on Current Industrial Policy Priorities). This was followed in March 1994 by the more comprehensive and integrated Outline of State Industrial Policies for the 1990s, which emphasised the development of mainstay and hightechnology industries, and the need to readjust the composition of foreign trade by strengthening manufacturing competitiveness.

Strategic industries, or 'pillar industries', were identified based on their importance to China's national security and economy (e.g. defence, coal, electric power and grid, telecommunications, petroleum and petrochemical, civil aviation and shipping) and growth potential (e.g. alternative-fuel cars, biotechnology, environmental and energy-saving technologies, alternative energy, advanced materials, new-generation information technology, and high-end equipment manufacturing). Each targeted sector received a policy package of complementary measures (e.g. tariff and non-tariff barriers, import quotas, local content requirements, licensing systems, tax exemptions, subsidised lands, and subsidised loans from state-owned policy banks) and relied increasingly on SOEs. The automobile and semiconductors industries, for example, were guaranteed market protection in exchange for technology transfer, while increases in companies' production scale were reached through government-led mergers and acquisitions (Lo \& Wu, 2014).

At the firm level, China sought to develop a 'national team' of state enterprises in strategic industries (Nolan, 2001; Sutherland, 2003). SOEs benefited from incentives and preferential loan terms. Between 1998 and 2003, SOEs received 65\% of all commercial bank loans, despite accounting for only $25 \%$ of China's economy (Ferri \& Liu, 2010:54). Imputed interest rates on debts offered to SOEs were also found to be $20 \%$ to $25 \%$ lower than that offered to private enterprises between 1999 and 2003 (Ferri \& Liu, 2010:55).

With legislation on bank loans having a significant industrial policy element, ${ }^{10}$ firms from prioritised industries benefited from subsidised loans drawn from state-owned 'policy banks',

\footnotetext{
10 Chapter IV, Article 34 of the 1995 Law of the People's Republic of China on Commercial Banks highlights that "[a] commercial bank shall conduct its loan business in accordance with the need for the development of the national economy and social progress and under the guidance of the state industrial policy".
} 
such as the Export-Import (Exim) Bank of China, the Agricultural Development Bank of China (ADBC) and the China Development Bank (CDB). Today they are still critical industrial policy arms for the implementation of industrial policy. The overall financial infrastructure was also given a pro-industrial development vocation by law.

Foreign direct investment (FDI) policies were finally a key element in China's industrial policies, alongside industrial consolidation policies and strategic mergers and acquisitions (e.g. China Electronics Corporation's acquisition of Irico Group, a photovoltaic equipment manufacturer). The June 1995 Provisional Regulations of Guidance on Foreign Direct Investment mapped out guidelines for targeting FDI in desired high-technology sectors, and a list of encouraged, restricted or prohibited foreign investments was recorded in the Foreign Investment Industrial Guidance Catalogue ('National Catalogue'). ${ }^{11}$ Encouraged industries tended to involve high-end manufacturing, new and advanced technologies, energy efficiency and environmental protection.

To facilitate technological transfers from more advanced economies, China offered tax incentives to entice foreign companies to establish R\&D centres, and imposed technologyimport regulations and ownership restrictions. Conforming to the ownership restrictions, transnational corporations (TNCs) formed joint ventures with Chinese companies. Such joint ventures ultimately allowed the state to retain effective control over foreign affiliates so as to advance Chinese interests (Roehrig, 1994).

Sectoral policies, industrial finance and FDI policies were also complemented by a new set of technology and cluster policies aimed at advancing domestic competencies in manufacturing and building integrated industrial systems. The Innovation Clusters programme was aligned with the development of National High Tech Zones (NHTZs) and Special Economic Zones (SEZs). The geographical distribution of public as well as private foreign investment was also centrally planned. Coastal areas, such as Guangdong and Fujian, were prioritised during the early days of the open-door policy while, more recently, inland areas have been the main targets of infrastructural investment. Emphasis was placed on developing clusters in different towns and cities, with unique pillar industries (e.g. Shunde specialises in electrical goods, while manufacturing towns such as Xiaolan specialises in locks and electronic acoustics and Guzhen in lighting fittings) (Zhang, 2013).

China's automobile industry offers an example of an industry that benefited from this complex package of industrial policies. Before the 1980s, the automotive industry largely comprised of SOEs, including First Automobile Works (FAW), Beijing Automotive Industry Corporation (BAIC), Dongfeng Motor Corporation and Shanghai Automotive Industry Corporation (SAIC). In the 1980s, the automotive industry was identified as one of China's pillar industries that would drive its economic development. Although foreign investors benefited from tax exemptions and subsidised land, they were highly regulated, with local content requirements and joint venture rules with indigenous firms (foreign shareholding was capped at 50\%). Examples of early joint ventures include BAIC and American Motors Company, and SAIC and Volkswagen. Using an infant industry strategy, import tariffs and quotas were imposed, with import tariffs reaching as high as $200 \%$ to $300 \%$ in the 1980 s and $100 \%$ to $200 \%$ in the early-

\footnotetext{
11 Industries not listed in the published categories (encouraged, restricted and prohibited) were implicitly 'permitted'
} industries. 
1990s (Huang, 2003:260). It was only in the late 1990s that the government loosened entry restrictions on foreign automobile manufacturers.

The market liberalisation agenda in the second part of the 1990s slightly downsized Chinese industrial policy efforts (agriculture, infrastructure, construction and services were included in the list of pillar industries). However, the Tenth Five Year Plan (2001-2005) marked the beginning of renewed systemic industrial and technology policy efforts.

A number of other policy measures have been introduced since 2005 as part of the $11^{\text {th }}$ and $12^{\text {th }}$ five-year plans. The policy model has increasingly relied on the involvement of provinces and municipalities, especially in the implementation of national plans such as those regarding sectoral policies. This is the case, for example, in the automotive sectoral policies (after 2011), as well as other industries like the photovoltaic sector. Policy coordination is achieved through the National Development and Reform Commission (NDRC), which drafts industrial plans for the State Council, but also collect inputs from the CCP Central Committee, and provincial and municipal governments (Dorn \& Cloutier, 2013). As a result of this accelerated process of structural change and the new industrial policy approach, China has entered a path of indigenous innovation (zizhu chuangxin).

A recent MIT study (Berger, 2013:145) has shown that, until 2005, there was limited evidence of domestic innovation capabilities. However, over the last four years, companies in high-tech sectors have developed scale-up capabilities (increasingly mastering the scale-up of complex system products and processes, translating into advanced product design and advanced manufacturing, and reducing the time to the market). Companies have also developed redesign, reverse and re-engineering competencies (re-assembling foreign components, changing functions, materials, and product characterisation). Thus these companies are increasingly able to produce products with "Japanese [good enough] quality at Chinese prices", making them the most striking example of the success of China's new industrialisation policies.

\section{Technology and R\&D financing policies: The Innofund case study}

Since the 1980s, China has adopted several technology and R\&D financing policies. In 1986, the National High-Tech Development Plan (also known as the 863 Plan) introduced the first articulated national technology strategy targeting biotechnology, space, information technology, laser technology, automation, energy, and new materials. Over the years, this technology plan was updated to include emerging technologies, such as telecommunications (1992) and marine technology (1996). Another programme, called the Torch Programme, was initiated in 1988. It promoted (i) hi-tech cluster development around Science and Technology Industrial Parks (STIPs), Software Parks, and Productivity Promotion Centers (Innovation Clusters); (ii) high-tech business start-up services (Technology Business Incubators); and (iii) financial services for innovation (Innofund and Venture Guiding Fund).

The Innofund was set up in 1999 as a special government R\&D programme. It aims to "facilitate and encourage the innovation activities of small and medium-technology based enterprises (SMTEs) and commercialization of research by way of financing, trying to bring along and attract outside financing for corporate R\&D investment of SMTEs" (Innofund institutional website). The Innofund has precisely defined eligibility criteria and provides 
different types of financial support, targeting different types of companies at different stages of development - from loan interest subsidies to equity investment.

To be eligible, companies must meet the following criteria: i) the project should comply with national industrial technology policies; ii) it should exhibit high potential for social and economic impact; and iii) it should be competitive in the market. Companies interested in applying for financing should be a business corporation with no more than 500 employees, $30 \%$ of whom must have received higher education. Moreover, the company must also show that it has an annual R\&D investment of at least $3 \%$ of total sales, and the number of employees dedicated to $R \& D$ should be at least equal to $10 \%$. If the company is operating in an industrial sector with high economies-of-scale potential, it must also exhibit good economic performances.

Among qualifying companies (Di Guo et al., 2016), the following projects are given priority:

i. Projects with advanced technology content or independent intellectual property rights and high value added;

ii. Projects established by researchers or oversees returnees interested in commercialising their scientific achievements;

iii. Innovation projects jointly initiated by firms, universities and other research institutions; and

iv. Projects that utilise new and advanced technologies to drive industrial restructuring in traditional sectors (especially stock assets revive) and job creation.

Companies can apply for three different forms of financing. This is a key feature of this programme, as it allows for targeted industrial financing acknowledging different company financial needs. Innofund offers several forms of financing:

i. Appropriation: is provided as start-up capital for small firms created and owned by a researcher with scientific achievement and potential for commercialisation of the innovation.

ii. Partial subsidies: are offered to SMEs engaged in the development of a new product or the setting up of a new production pilot line. The total amount of subsidies is between one and two million renminbi (RMB) and firms are required to match the subsidy one to one.

iii. Interest-free loans: are provided to SMEs interested in expanding and scaling up the production of innovative products as a substitute for commercial bank funding.

iv. Equity investments: are only dedicated to investments in advanced technologies, for companies with high capacity and for products with high potential in emerging industries. Even when companies qualify for an equity investments, the latter should not be more than $20 \%$ of the registered capital of the investee firm. In some cases, the government can also provide bank loan insurance to improve financing terms from commercial banks.

The governance structure of such articulated programmes relies on two levels of governance agencies.

The Innofund Administration Centre (IAC) is the central authority under the Ministry of Science and Technology (MOST) and responsible for: i) the identification of the preferred application 
technology fields and industries and developing the application guidelines; ii) the ex-ante screening and evaluation of the applications; iii) releasing the contract with the selected firms; and iv) post-investment project assessment. All of these funding operations are also regulated and monitored by the Ministry of Finance (MOF), which approves the yearly budget, releases funding to the IAC twice a year and assesses its performance. The MOF and MOST produce joint annual reports on the Innofund programme to be reviewed by the State Council.

At the local level, Innofund offices are distributed in each province and operate under the Provincial Science and Technology Committee. After 2005, the provincial offices received much more power from the Centre and were put in charge of performing many of the functions originally performed by the central IAC. In particular, before 2005, the provincial offices were simply recommendatory bodies and, when the central office approved a funding application, the provincial Bureau of Finance was expected to co-fund the allocated funding by $50 \%$. After 2005, the provincial committees have been increasingly involved in the project selection process, and a new application and screening system has also been introduced. Local Innofund offices have been given a $30 \%$ weight in the final decision made by the central IAC office, as part of a move towards more decentralisation and greater involvement of local government in decision making as well as funding.

The exclusive ex-ante project screening performed by the central IAC presented two main challenges. First, the hierarchical system presented several inefficiencies and was relatively less transparent. Second, the central decision was potentially less effective, as local offices have a much better understanding of the local industrial conditions and opportunities. As a result of this de-centralisation, the policy process was also made more responsive and able to monitor the investments more closely. According to Guo et al. (2016), the system has become even more articulated since 2005, with provincial offices involving more agencies in the decision process and delegating decisions to lower levels. These innovations in the governance settlement have been particularly frequent in the most advanced regions, including Zhejiang. The governance de-centralisation has also been mirrored by an increasing shift from central transfer to local resources mobilisation. Since 2005, the provincial governments have increased their investments in the Innofund scheme six times.

Between 1999 and 2011, Innofund provided more than 19 billion RMB to more than 30000 projects. A large majority of these were supported through appropriation (around 27000 ), while all the others received several types of financial support, subsidy credits, bank loan insurance and equity investments. According to official reports, Innofund has a 1:11 multiplier effect in terms of inducing external financing, and has succeeded in the incubation of today's world-leading companies, including the ICT giant Huawei. After only ten years of operation, 82 of the 273 companies publicly listed on China's SME Stock Exchange were former Innofund-supported companies. 


\subsection{Case study 3: Malaysia and the diversification of the economy}

Industrial policy in Malaysia started in the second half of the 1960s with the Investment Incentives Act of 1968, when import substitution policies and SOEs development were aligned with a strong export promotion package of interventions (Lall, 1995; Rasiah \& Shari, 2001)12.

The need to coordinate a more articulated package of policies led to the establishment of the Malaysian Industrial Development Authority (MIDA), which was set up in the late 1960s. The authority played a key strategic role in the coming two decades, although problems in the coordination of policy interventions persisted.

MIDA was the institution in charge of identifying and targeting strategic sectors for government. With a focus on semiconductors and other electronic components assembly, the electronics industry was highly labour intensive and allowed for short learning cycles in related electrical products, such as audio electric systems (Lee, 2013). MIDA targeted the semiconductor assembly industry and a number of US-based multinational corporations were offered a comprehensive package of incentives, including tax holidays and profit-repatriation guarantees. Many of these incentives were tied to investments in training, export performance and R\&D activities. Incentive packages favoured export-oriented firms in particular. For example, the government supported duty drawback schemes along with export incentives offering double deduction benefits on corporate tax. Low wages and an English-speaking labour force also played an important role in attracting foreign companies. Finally, local supply chains were also promoted with the introduction of local content policy measures, especially for export-oriented manufacturers (Lall, 1995).

The establishment of export-processing zones and industrial areas was also promoted in 1971. One of these zones, based in Penang - the Bayan Lepas Export Processing Zone was home to the first electronic industry in Malaysia. Many companies relocated their electronics plants to one of these zones in the following decade, leading to the establishment of local production systems around semiconductors and electronic components (Rasiah, 2010). A number of these companies increasingly developed productive capabilities in higher technology and higher value-added products through continuous investments in skills and R\&D activities.

In 1990, Malaysia became the world's largest exporter of semiconductors and amongst the largest exporters of disk drives, telecommunications apparatus, audio equipment, room airconditioners, calculators, colour televisions, and various household electrical appliances. More critically, by 1992 , almost $90 \%$ of manufacturing of electronic products was being conducted by TNC affiliates (Athurkorala \& Menon, 1999). The strategic integration into the electronics value chain had led to the development of a dense local production system made of specialised suppliers.

\footnotetext{
12 In the early 1970, the New Economic Policy (NEP) was launched as a response to the socio-economic crisis and related racial conflicts in 1969, in particular high levels of poverty and inequality concentrated in the Malay population. One of the instruments introduced to address these conflicts and improve the economic situation of indigenous Malays (Bumiputera) was the establishment of new SOEs and, later, the transfer to Malay private ownership. As a result, from only 10 SOEs in 1957, by 1974 there were 82 SOEs in Malaysia, alongside 185 joint ventures with the private sector (Hui \& Canak, 1981).
} 
Between 1970 and 1990, despite this export-oriented shift in industrial policy, Malaysia retained and expanded its public sector investments and retained import-substitution policies. The public sector financing of industrial investments peaked in this period, reaching almost $30 \%$. Among the targeted sectors were chemical and photographic supplies, transport equipment, electrical machinery, mineral products and precious stones. These and other manufactured items were subject to discretionary import licensing (WTO, 1997).

Starting with the New Development Policy (NDP) in the second half of the 1980s until the mid2000s, Malaysia fully embraced the East Asian model pioneered in the region by Japan, and later by South Korea, Singapore and China. The Industrial Master Plans (IMP1 1986-1995, IMP2 1995-2006) targeted the development of heavy industries, including automobile and chemicals. These sectors were given import protection, and investments were made to develop more advanced technological capabilities. Specific attention was given to skills training, technical standards, and science and technology institutions through a technology action plan, which stimulated R\&D in private enterprises. Finally, Technology Transfer Agreements (TTAs) were promoted to enable domestic firms to obtain the necessary technologies to meet international quality and process standards. During the period 1989 to 1996, a total of 1124 TTAs were approved by the MITI. Royalty payments were made in 467 of these agreements, most of which concerned the electronics sector (WTO, 1997).

To support and induce multinational corporations in EPZs to upgrade their operations and move towards higher value tasks, the government invested heavily in technical training. For example, in 1989, the government established the Penang Skills Development Corporation (PSDC). The steering committee was headed by three leading companies - Motorola, HewlettPackard and Intel - and included another 24 'founder firms' providing equipment, production technologies and highly skilled engineers and managers to teach at the newly established campus funded by the state of Penang. In 1996, the PSDC was ranked among the top ten workforce development institutions in the world, according to a USAID study. In the following years, Penang remained at the forefront of Malaysia's global value chain integration and technological upgrading. Notably, in 2005 Penang was awarded cyber-city status as part of the Multimedia Super IT Corridor initiative. PDC was also renamed InvestPenang in 2004, and FDI investments in biotechnology, including medical devices, automation-based medical devices, instrumentation and diagnostic tools, were targeted. To keep pace with this technological upgrading, the PSDC founded an intermediate institution called the Microelectronic Centre of Excellence.

The upskilling and advancement of the science and technology infrastructure proceeded hand in hand with targeted support of SMEs and local production systems. In 1993, for example, a soft loan policy for quality enhancement was introduced for Bumiputra-owned SMEs in the furniture and food-based industries. This was later extended to the automotive, electrical and electronics, plastics, machinery, engineering, and textiles sectors. Cluster-based industrial development programmes - such as the Industrial Linkage Programme (ILP) under the Small and Medium Industrial Development Corporation (SMIDEC) and the Vendor Development Programmes under the Ministry of Entrepreneur Development (MED) - were introduced in order to promote the use of locally made intermediate inputs through financial and technical assistance. 
MIDA also introduced a matching grant scheme to accelerate the shift of Malaysian-owned companies in targeted high value-added, high-technology innovation-based industries. The scheme, called the Domestic Investment Strategic Fund (DISF), matches companies' investments with a $50 \%$ grant i) for training and R\&D purposes; ii) to undertake outsourcing activities; iii) to comply with international standards; and iv) for licensing/purchase of technologies. These matching grants are also aligned with the sectoral industrial strategy, thus they privilege technological investments in renewable energy, advanced microelectronics, machinery and equipment, medical devices, pharmaceuticals and aerospace.

Industrial policy remains a key part of Malaysia's economic strategy today (Gustafsson, 2007; Jomo, 2007). In the Third Industrial Master Plan (IMP3), a broad planning blueprint for Malaysia's economic strategy between 2006 and 2020, the strategic manufacturing and services sectors were identified for promotion and growth (MITI, 2006). This included the electrical and electronics, medical devices, textiles and apparel, machinery and equipment, metals and transport equipment industries. Malaysia is also targeting a broader manufacturing base with more high value-added industries, such as pharmaceuticals and transport equipment.

Resource-based industries that were targeted included the petrochemicals, pharmaceuticals, wood, rubber, palm oil and food-processing industries. The palm oil industry remains a key sector prioritised by the government in the medium term

\section{Diversification of the local production system: The case of palm oil}

Among the early industries picked by Malaysia's government, the palm oil industry represented an example of an initially risky industry involving a non-native crop that eventually grew to achieve phenomenal international success. Malaysia accounts today for roughly half of the world's production of palm oil. In the words of Rock and Sheridan (2007:191), "the government's selective intervention in promoting smallholder palm oil production and the processing of crude palm oil may be the single most successful selective intervention in Malaysia".

In the 1960s, to diversify its traditional commodity export base, palm oil became the Malaysian government's 'crop of choice' (Pletcher, 1991:625). As palm oil crops need to be milled within 24 hours after harvesting, the government also identified and captured the opportunity to build strong linkages between agricultural and industrial production. ${ }^{13} \mathrm{~A}$ number of selective interventions were undertaken to grow internal capabilities and expanding the coverage of oil palm trees.

First, to encourage landowners of rubber to switch to palm oil production, replanting grants were offered to finance the replanting of old rubber trees with oil palm from 1962. Such grants greatly lessened the financial burden on smallholders and estates arising from switching crops. Second, foreign-owned oil palm estates were acquired and developed by the state. ${ }^{14}$ By the mid-1980s, the government had gained control of all the major plantations in Malaysia

\footnotetext{
13 The manufacture of crude palm oil, refined palm oil and palm kernel oil is classified under the manufacturing of food products (Division 10) in the Malaysian Standard Industrial Classification (DOSM, 2008).

14 Foreign-owned plantation companies were required to form subsidiaries domiciled in Malaysia. Majority ownership of these subsidiaries was then taken up by Malaysia's economic development corporations Permodalan Nasional (PERNAS) and, subsequently, Permodalan Nasional Berhad (PNB).
} 
(Pletcher, 1991:630). Such initiatives dramatically altered the composition of Malaysia's output. Between 1960 and 1970, oil palm acreage (including replanted land and new plantations) grew by $13 \%$ p.a. (from 40064 hectares to 135570 hectares), leading to a $16 \%$ p.a. growth in output (from 90000 tonnes to 396000 tonnes) (Yusof \& Bhattasali, 2008:5). By 2012 , the total planted area had expanded further by more than 37 -fold to 5.08 million hectares (MPOB, 2013).

The government provided strong institutional support and facilitated coordination between the public and private sectors by setting up the Palm Oil Registration and Licensing Authority (PORLA), the Palm Oil Research Institute of Malaysia (PORIM), and the Malaysian Palm Oil Promotion Council (MPOPC). PORLA, PORIM and MPOPC were responsible for regulation and licensing, specialised training and public sector $R \& D$, and export promotion respectively. In 2000, to harness synergies between related functions, PORLA and PORIM were merged to form the Malaysian Palm Oil Board (MPOB).

Not merely content with the direct economic contributions of palm oil, the government actively sought to develop targeted downstream industries, such as the palm oil processing, oleochemicals, ${ }^{15}$ biotechnology, biodiesel and biomass industries (see Malaysia's industrial master plans - MITI 1986, 1996 and 2006). Defying earlier sentiment that Malaysia lacked a comparative advantage in palm oil processing (see Little and Tipping (1972), for example), the government undertook a slew of targeted measures, including fiscal incentives and price distortions, to grow downstream capabilities.

First, fiscal incentives were used to attract investments in strategic areas related to palm oil. Under the 1968 Investment Incentives Act, qualifying oil palm firms enjoyed two years of (renewable) corporate tax exemptions, and eight years of excess profit and development tax exemptions (see Rasiah, 2006). Pioneer status awards, offered before 1974, granted palm oil refineries tax exemptions for seven years. ${ }^{16}$ Tax exemptions were also offered on the basis of export performance and capital investments.

Second, higher duties on crude palm oil exports and tax exemptions ${ }^{17}$ on processed palm oil exports greatly skewed producers' incentives towards the latter. Following from this, the 1970s were characterised by significant price distortions in palm oil exports (Athukorala \& Loke, 2009). ${ }^{18}$ By 1994, Malaysia refined $99 \%$ of crude palm oil, a significant jump from $10 \%$ in 1975 (Gopal, 1999:363). According to Jomo and Rock (1998), the export tax spurred the industry to upgrade its industrial and technological capabilities, and eventually to define the global technological frontier in palm oil refining.

\footnotetext{
15 The oleochemicals industry includes basic oleochemicals (e.g. fatty acids and glycerine), oleochemical derivatives (e.g. fatty esters and metallic stearates), oleochemical preparations (e.g. soap and cosmetics) and other palm oil-based products (e.g. printing ink and polyols).

${ }^{16}$ Between 1969 and 1974, nine palm oil refineries received the pioneer status award (Rasiah, 2006:174). Pioneer status awards came under the auspices of the 1958 Pioneer Industry Ordinance.

17 The extent of tax exemptions (full or partial) on processed palm oil exports depended on the degree of processing of the crude palm oil.

18 During the periods 1970 to 1974 and 1975 to 1979, the nominal rates of assistance (NRAs), measuring the gap between domestic prices and free-market prices, were estimated to be $-15.2 \%$ and $-15.0 \%$ respectively (Athukorala \& Loke, 2009:214).
} 
Third, bleaching earth, a key ingredient in the palm oil-processing industry, was initially subjected to tariffs and import quotas until internal production capabilities were built. However, to cap costs during the import-substitution phase, subsidies were provided such that the price of bleaching earth purchased by domestic industries was similar to world prices.

Fourth, various policies dovetailed to promote the development of downstream industries. For instance, the 2006 Malaysian Biofuel Policy aimed to facilitate the gradual substitution of diesel fuel with palm oil.

To promote the development of the palm oil industry, international restrictions on industrial policy were also occasionally circumvented. For instance, the Palm Oil Credit and Payment Arrangement (POCPA) scheme was introduced in 1992 to provide a two-year credit facility for countries purchasing palm oil from Malaysia. ${ }^{19}$ However, despite the IMF's imposition of a three-month rule for clearing and repayment arrangements in 1994, US\$500 million were still allocated to the POCPA scheme by 2002 , with US $\$ 227$ million of credit extended to nine countries, including Cuba and Pakistan (see Gustafsson, 2007:47-48). ${ }^{20}$

\section{Concluding remarks and Implications for South Africa}

This study assesses the development and industrialisation challenges facing South Africa as a middle-income country, moreover, as a country that is arguably caught in the middle-income trap. 'Stuck in the middle', South Africa - alongside a number of middle-income countries has been unable to break out of its middle-income status. To the contrary, South Africa has been falling down global GDP rankings over a long period of time. Having previously had the highest income per capita of the group of comparator countries analysed here, South Africa has since been overtaken by Brazil and Malaysia, and China is set to overtake South Africa in 2018. Far from catching up with advanced economies, South Africa is itself being caught up with by other countries, including those that were previously of low-income status.

This poor growth performance is concomitant with South Africa's failure to take forward its industrialisation and to upgrade the structure of its economy. To the contrary, the country has experienced premature deindustrialisation. Our analysis of the global evidence on premature deindustrialisation benchmarks South Africa's structural position and trajectory in the global context. The share of manufacturing in total employment in South Africa in 2015 is shown to be (a bit) below the share that would be predicted based on international patterns. Moreover, this share is falling further in South Africa, taking the country further below its predicted share.

Adding to the concern about the quantitative share is the composition of South Africa's manufacturing sector and exports. With some exceptions, the profile of South African manufacturing production and exports does not show the desirable patterns of structural transformation, which would include growth in domestic value added, movement up the value chain, and increasing focus on products that show potential for cumulative productivity increases and are demand-dynamic. South Africa is also lagging in terms of innovation and in

\footnotetext{
${ }^{19}$ Interest rates were determined by the London Inter-Bank Offered Rate (LIBOR). As part of the POCPA, barter and counter-trade arrangements could also be included.

20 Other countries participating in Malaysia's POCPA included Algeria, Bosnia and Herzegovina, Iran, Iraq, Myanmar, North Korea and Sudan.
} 
the development and application of KETs that would enable the country to become competitive in the manufacture of complex products and to gain from the opportunities associated with Industry 4.0.

Over the last years, South Africa has relied on several ambitious rounds of industrial policy, including sectoral targeting as in the case of the automotive industry. The international industrial policy experiences of countries like Brazil, China and Malaysia offer insights into the challenges associated with the implementation of different industrial policy tools and their coordination.

The Brazilian case highlights the importance of promoting the development of public technology intermediaries supporting the absorption, adaptation and diffusion of technologies. The Embrapa case study is particularly important for middle-income countries, as it suggests opportunities for technological development and value addition at the agriculturalmanufacturing sectoral interface.

The historical experience of China stresses inter alia the importance of long-term commitment and a staged approach to industrial transformation, especially with respect to technological advancement in the manufacturing sector. The Innofund is presented as a successful case of a funding scheme for technology policy. This specific case also shows the importance of supporting industrial policy implementation with responsive multi-governance institutions.

The Malaysia case study points to the importance of a diversification strategy. Product and sectoral diversification is a key driver of sustained industrialisation and the development of a well-integrated domestic production system. The Malaysian experiences in the electronics industry and in palm oil emphasise the importance of developing production and technological linkages in the domestic economy, while integrating into global production networks.

The lessons learned from the country cases reviewed in the paper point to three important policy recommendations.

First, there are significant opportunities for value addition and technological development in agro-business value chains. The industrialisation of agriculture opens new venues for increases in productivity, upgrading in global markets and diversification. However, in order to capture these opportunities, public technology intermediaries must provide key technology and product services to reach product quality standards, and transform agricultural activities into highly productive industrial processes.

Second, the promotion of technological upgrading in manufacturing industries cannot be done simply by jumping to frontier technologies - i.e. the so-called fourth industrial revolution. The China case study, in particular, emphasises how the building of a solid productive and technological capability foundation over several years is a precondition for innovation across several industrial fields. The other lesson is that institutions promoting technological innovation will have to change over time to respond to the changing nature of the innovation challenges firms face in the fast-changing global landscape.

A third policy lesson is that, to increase value addition and value capturing in the domestic economy, countries need to target the development of their local production system. The 
building of integrated supply chains in the domestic economy gives countries sustained industrial and productivity growth. Therefore, industrial policy focusing on the attraction of a multinational or the setting up of an export-promotion zone must be fully coordinated with other policy measures that induce the real industrialisation process.

Reversing premature deindustrialisation in South Africa will not result from the use of one of these instruments. Instead, it will depend on the coordination of a feasible set of interventions reinforcing each other in a coordinated manner. In particular, strategic forward integration and upgrading in global value chains is a complex process, as it entails both linking domestic players to foreign companies and markets, while at the same time building local supply chains of producers.

The development of the local production system as a strategy to move beyond the middleincome trap also requires engaging with technical change, especially taking into consideration the multiple cross-system applications of modern technologies. While manufacturing remains a cornerstone for re-industrialisation and technological development in South Africa, new value-addition opportunities can be found at the interface of the other economic sectors and the intersection of different technology systems. Well-coordinated and coherent industrial policy packages are critical in shaping this new industrial ecosystem in South Africa and moving the country beyond the middle-income trap. 
Appendix 1: Premature deindustrialisation regression results

Table A1 shows the econometric results upon which the analysis in section 3 is based.

Table A1: Regression results

\begin{tabular}{lll}
\hline & \multicolumn{2}{l}{$\begin{array}{l}\text { Dependent variable: Share of manufacturing in total } \\
\text { employment (In) }\end{array}$} \\
\hline & $\mathbf{2 0 0 5}$ & $\mathbf{2 0 1 5}$ \\
\hline GDP per capita (In) & $1.177^{* * *}$ & $1.130^{* * *}$ \\
& $(0.259)$ & $(0.357)$ \\
\hline GDP per capita (In) & $-0.060^{* * *}$ & $-0.058^{* * *}$ \\
squared & $(0.015)$ & $(0.020)$ \\
\hline constant & $-3.061^{* * *}$ & $-3.001^{*}$ \\
& $(1.053)$ & $(1.523)$ \\
\hline $\mathrm{R}^{2}$ & 0.33 & 0.17 \\
\hline $\mathrm{n}$ & 148 & 148 \\
\hline \multicolumn{2}{c}{ Note: robust standard errors in parentheses below estimated coefficients. } \\
& &
\end{tabular}




\section{References}

ABDI (Brazilian Agency for Industrial Development). (2006), An Industrial Policy for Brazil, Brasilia: ABDI.

Alves, E. (2010), Embrapa: A success story of institutional innovation, Brasilia: Brazilian Agricultural Research Corporation.

Andreoni, A. (2014), 'Structural learning: Embedding discoveries and the dynamics of production', Structural Change and Economic Dynamics, 29, 58-74.

Andreoni, A. (2016), 'Varieties of industrial policy: Models, packages and transformation cycles', in Noman, A. and Stiglitz, J. (eds.), Efficiency, Finance and Varieties of Industrial Policy, New York: Columbia University Press, pp. 245-305.

Andreoni, A. (2018a), 'A generalized linkage approach to local production systems development in the era of global value chains, with special reference to Africa,' in Noman, A. and Stiglitz, J. (eds.), Quality of Growth in Africa, Columbia University Press.

Andreoni, A. (2018b), 'The architecture and dynamics of industrial ecosystems: Diversification and innovative industrial renewal in Emilia Romagna', Cambridge Journal of Economics, forthcoming.

Andreoni, A. and Chang, H.-J. (2014), 'Agricultural policy and the role of intermediate institutions in production capabilities transformation: Fundacion Chile and Embrapa in action', Paper presented at the DRUID Annual Conference, Copenhagen, Denmark.

Andreoni A. and Chang H.-J. (2016), 'Industrial policy and the future of manufacturing', Economia e Politica Industriale, 43 (4), 491-502.

Andreoni, A., Frattini, F. and Prodi, G. (2017), 'Structural cycles and industrial policy alignment: The private-public nexus in the Emilian packaging valley', Cambridge Journal of Economics, 41 (3), 881-904.

Arias, M.A. and Wen, Y. (2015), 'Trapped: Few developing countries can climb the economic ladder or stay there', Federal Reserve Bank of St. Louis, The Regional Economist, October.

Arip, M.A., Lau, S.Y. and Thien, S.F. (2013), 'Assessing the competitiveness of Malaysia and Indonesia palm oil related industry', World Review of Business Research, 3 (4), 138-145.

Arvanitis, R. and Qiu, H. (2008), 'Research for policy development: Industrial clusters in South China', in Graham, M. and Woo, J. (eds.), Fuelling Economic Growth: The Role of PublicPrivate Sector Research in Development, Ottawa: Practical Action Publishing, pp. 39-85.

Athukorala, P. and Menon, J. (1999), 'Outward orientation and economic development in Malaysia', World Economy, 22 (1): 119-139. 
Barbieri, E., Di Tommaso, M.R. and Bonnini, S. (2012), 'Industrial development policies and performances in Southern China: Beyond the Specialised Industrial Cluster Program', China Economic Review, 23, 613-625.

Beintema, N.M., Ávila, A.F.D. and Pardey, P.G. (2001), Agricultural R\&D in Brazil: Policy, Investments and Institutional Profile, Washington, DC: IFPRI, Embrapa and Fontagro, Ago.

Berger, S. (2013), Making in America, Cambridge: MIT Press.

Best, M. (1990), The New Competition, Cambridge MA: Harvard University Press.

Best, M. (2013). 'Greater Boston's industrial ecosystem: A manufactory of sectors', Technovation, 39-40, 4-13.

Brenahan, T. (2010), 'General purpose technologies', in Hall, B. and Rosenberg, N. (eds.), Handbook of Economics of Innovation, Amsterdam: Elsevier.

Chang, H.-J. (2011), 'Industrial policy: Can we go beyond an unproductive debate?' in Lin, J.Y. and Pleskovic, B. (eds.), Lessons from East Asia and the Global Financial Crisis, Annual World Bank Conference on Development Economics 2010, 23-24 June, Seoul, South Korea.

Chang, H.-J. and Andreoni, A. (2016). 'Industrial policy in a changing world', Cambridge Journal of Economics 40 Years Conference, 12-13 July, Cambridge.

Dahmen, E. (1989), 'Development blocks in industrial economics', reprinted in Carlsson, B. and Henriksson, R. (eds.), Development Blocks and Industrial Transformation, Stockholm: The Industrial Institute for Economic and Social Research, pp. 136-149.

Davies, K. (2013), 'China investment policy: An update', OECD Working Papers on International Investment 2013/01, Paris: OECD Publishing.

Dorn, J. and Cloutier, T. (2013), 'Report on Chinese industrial policies', King \& Spalding, available at: http://bucket-gw-cni-static-cmssi.s3.amazonaws.com/legacy/app/conteudo_18/2013/04/12/3558/20130412174031359432u .pdf

Embrapa. (2007), Tropical Agriculture: Brazil Building the Future, Brasilia: Embrapa.

Embrapa. (2012), Brazilian Agriculture: Development and Challenges, Brasilia: Embrapa.

Evans, P. (1995), Embedded Autonomy: State and Industrial Transformation, Princeton: Princeton University Press.

Falco, M., Mereguetti, M., Stern, C. and Erguney, O. (2011), 'Brazil mining', Engineering and Mining Journal (E\&MJ), Jacksonville: E\&MJ. 
Ferraz, J., Figuereido, C., Leal, C., Marques, F. and Miterhof, M. (2013), 'Financing development: The case of BNDES', in Stiglitz, J. and Lin, J.Y. (eds.), The Industrial Policy Revolution I, Basingstoke: Palgrave.

Ferri, G. and Liu, L. (2010), 'Honor thy creditors beforan thy shareholders: Are the profits of Chinese state-owned enterprises real?' Asian Economic Papers, 9 (3), 50-71.

Figueiredo, P. and Piana J. (2016), "When "one thing (almost) leads to another": A micro-level exploration of learning linkages in Brazil's mining industry', Resource Policy, 49, 405-414.

Gereffi, G. (2013), 'Global value chains in a post-Washington consensus world', Review of International Political Economy 21 (1): 9-37.

Gill, I. and Kharas, H. (2007), An East Asian Renaissance. Washington, DC: World Bank.

Gopal, J. (1999), 'Malaysia's palm oil refining industry: Policy, growth, technical change, and competitiveness', in Jomo, K.S., Felker, G. and Rasiah, R. (eds.), Industrial Technology Development in Malaysia: Industry and Firm Studies, London: Routledge, pp. 360-395.

Guo, D., Guo, Y. and Jiang, K. (2016), 'Government-subsidized R\&D and firm innovation: Evidence from China', Research Policy, 45 (6), 1129-1144, available at: http://dx.doi.org/10.1016/j.respol.2016.03.002

Gustafsson, F. (2007), 'Malaysian industrial policy, 1986-2002', in Jomo, K.S. (ed.), Malaysian Industrial Policy, Singapore: NUS Press, pp. 35-55.

Hosono, A. and Hongo, Y. (2012), Cerrado Agriculture: A Model of Sustainable and Inclusive Development, Tokyo: Japan International Cooperation Agency Research Institute.

Huang, Y. (2003), Selling China: Foreign Direct Investment During the Reform Era, Cambridge: Cambridge University Press.

Hui, L. and Canak, W. (1981), 'The political economy of state policies in Malaysia', Journal of Contemporary Asia, 11 (2): 208-224.

ICMM. (2013), 'The mining sector in Brazil: Building institutions for sustainable development', Report Mining: Partnership for Development, London: ICMM, available at: https://www.icmm.com/en-gb/publications/mining-partnerships-for-development/the-miningsector-in-brazil-building-institutions-for-sustainable-development

Jomo, K.S. (2007), 'Industrialization and industrial policy in Singapore', in Jomo K.S. (ed.), Malaysian Industrial Policy, Singapore: NUS Press, pp. 1-34).

Jomo, K.S. and Rock, M. (1998), 'Economic diversification and primary commodity processing in the second-tier South-East Asian newly industrializing countries', UNCTAD Discussion Papers No. 136, Geneva: United Nations Conference on Trade and Development. 
Jovanovic, B. and Rousseau, P. (2005), 'General purpose technologies', in Aghion, P. and Durlauf, S.N. (eds.), Handbook of Economic Growth, vol. 1B, Amsterdam \& Oxford: Elsevier B.V.

Khan, M.H. (2010), Political Settlements and the Governance of Growth-enhancing Institutions, Mimeo, London, SOAS University of London.

Khan, M.H., Andreoni, A. and Roy, P. (2016), 'Anti-corruption evidence: A strategic approach', Mimeo, ACE Anti-Corruption Evidence Research Consortium, available at: https://ace.soas.ac.uk/

Kirby, W.C. (1990), 'Continuity and change in modern China: Economic planning on the mainland and on Taiwan, 1943-1958', The Australian Journal of Chinese Affairs, 24, 121-141.

Kupfer, D., Ferraz, J. and Marques, F. (2013), 'The return of industrial policy in Brazil', in Stiglitz, J. and Lin, J. (eds.), The Industrial Policy Revolution I, Basingstoke: Palgrave.

Lall, S. (1995), 'Malaysia: Industrial success and the role of the government', Journal of International Development, 7 (5), 759-773.

Landesmann, M. (1992), 'Industrial policies and social corporatism', In Pekkarinen, J., Pohjola, M. and Rowthorn, R. (eds.), Social Corporatism: A Superior Economic System, New York: Oxford University Press, pp. 242-279.

Lee, K. (2013), Schumpeterian Analysis of Economic Catch-up: Knowledge, Path-creation and Middle-income Trap, Cambridge: Cambridge University Press.

Lin, J.Y. (2017), 'Industrial policies for avoiding the middle-income trap: A new structural economics perspective', Journal of Chinese Economic and Business Studies, 15 (1), 5-18.

Lo, D. and Wu, M. (2014), 'The state and industrial policy in Chinese economic development', in Salazar-Xirinachs, J.M., Nubler, I. and Kozul-Wright, R. (eds.), Transforming Economies, Geneva: ILO, pp. 307-326

Marukawa, T. (2011), 'Technology acquisition by indigenous firms: The case of the Chinese and Indian automobile industries', in Ohara, M., Vijayabaskar, M. and Lin, H. (eds.), Industrial Dynamics in China and India: Firms, Clusters, and Different Growth Paths, Basingstoke: Macmillan Publishers Limited, pp. 63-79.

Matthey, H., Fabiosa, J. and Fuller, F. (2004), 'Brazil: The future of modern agriculture?' MATRIC Briefing Paper No. 8, Ames, lowa: lowa State University.

MIIT (Ministry of Industry and Information Technology of the People's Republic of China). (2013), Guidance on Corporate Mergers and Acquisitions to Accelerate the Growth of Key available

at: http://www.miit.gov.cn/n11293472/n11293832/n11293907/n11368223/15130615.html 
Milberg, W. and Winkler, D. (2013), Outsourcing Economics. Global Value Chains in Capitalist Development, Cambridge: Cambridge University Press.

MITI (Malaysia Ministry of International Trade and Industry). (2006), IMP3: Third Industrial Master Plan, 2006-2020: Malaysia - Towards Global Competitiveness, Kuala Lumpur: Percetakan Nasional Malaysia Berhad.

Nolan, P. (2001), China and the Global Economy: National Champions, Industrial Policy, and the Big Business Revolution, New York: Palgrave.

OECD (Organisation for Economic Co-operation and Development). (1999), Boosting Innovation: The Cluster Approach, Paris: OECD.

OICA (Organisation Internationale des Constructeurs d'Automobile). (2014), OICA World Motor Vehicle Production Statistics Database, Paris: OICA.

Palma, J.G. (2005), 'Four sources of "deindustrialisation" and a new concept of the "Dutch disease"', in Ocampo, J.A. (ed.), Beyond Reforms: Structural Dynamics and Macroeconomic Vulnerability, New York: Stanford University Press and World Bank.

Palma, J.G. (2008), 'Deindustrialisation, premature deindustrialisation, and the Dutch disease', in Blume, L.E. and Durlauf, S.N. (eds.), The New Palgrave: A Dictionary of Economics, 2nd edition, Basingstoke: Palgrave Macmillan, pp. 401-410.

Penrose, E.T. (1959), The Theory of the Growth of the Firm, Oxford: Oxford University Press.

Pletcher, J. (1991), 'Regulation with growth: The political economy of palm oil in Malaysia', World Development, 19 (6), 623-636.

Poncet, S. (2010), 'Inward and outward FDI in China', in Greenaway, D., Milner, C. and Yao, S. (eds.), China and the World Economy, Croydon: Palgrave Macmillan, pp. 112-134.

Rasiah, R. (2006), 'Explaining Malaysia's export expansion in palm oil and related products', in Chandra, V. (ed.), Technology, Adaptation and Exports: How Some Developing Countries Got It Right, Washington, DC: World Bank, pp. 163-192..

Rasiah, R. (2010), 'Are electronics firms in Malaysia catching up in the technology ladder?' Journal of the Asia Pacific Economy, 15 (3): 301-319.

Rasiah, R. and Shari, I. (2001), 'Market, government and Malaysia's new economic policy', Cambridge Journal of Economics, 25 (1), 57-78.

Reinhardt, N. (2000), 'Back to basics in Malaysia and Thailand: The role of resource-based exports in their export-led growth', World Development, 28 (1), 57-77.

Rock, M.T. and Sheridan, M. (2007), 'The political economy of industrial policy in Malaysia', in Jomo, K.S. (ed.), Malaysian Industrial Policy, Singapore: NUS Press, pp. 179-221. 
Rowthorn, R. (1994), 'Korea at the cross-roads', Working Paper No. 11, Cambridge: Centre for Business Research.

Simeh, A. and Ahmad, T.M.A.T (2001), 'The Case Study on the Malaysian Palm Oil', Regional Workshop on Commodity Export Diversification and Poverty Reduction in South and SouthEast Asia, Bangkok: United Nations Conference on Trade and Development.

Stiglitz, J.E. (1996), 'Some lessons from the East Asian miracle,' The World Bank Research Observer, 11 (2), 151-177.

Sutherland, D. (2003), China's Large Enterprises and the Challenge of Late Industrialisation, London: RoutledgeCurzon.

Tassey, G. (2007), The Technology Imperative, Cheltenham: Edward Elgar.

Tassey, G. (2010), 'Rationales and mechanisms for revitalizing US manufacturing R\&D strategies', Journal of Technology Transfer, 35, 283-333.

Tregenna, F. (2009), 'Characterising deindustrialisation: An analysis of changes in manufacturing employment and output internationally', Cambridge Journal of Economics, 33 (3), 433-466.

Tregenna, F. (2015), 'Deindustrialisation, structural change and sustainable economic growth', United Nations Industrial Development Organization, Inclusive and Sustainable Industrial Development Working Paper Series, Working Paper 02 | 2015.

Tregenna, F. (2016), 'Deindustrialisation and premature deindustrialisation', in Ghosh, J., Kattel, R. and Reinert, E. (eds.), Elgar Handbook of Alternative Theories of Economic Development, Cheltenham: Edward Elgar.

UN (United Nations). (2013), UN ComTrade Database. New York: United Nations.

Wade, R. (2016), 'Industrial policy in response to the middle income trap and the third wave of the digital revolution', Global Policy, 7 (4), 469-480.

World Bank. (2013), China 2030: Building a Modern, Harmonious, and Creative Society, Washington, DC: World Bank

WTO (World Trade Organization). (1997), 'Trade policy review, Malaysia', Report PRESS/TPRB/67, Geneva: WTO.

Yusof, Z.A. and Bhattasali, D. (2008), 'Economic growth and development in Malaysia: Policy making and leadership', Commission on Growth and Development Working Paper No. 27, Washington, DC: World Bank.

Zhang, X. and Long, G. (1997), 'China's industrial policies in the process of marketization', in Masuyama, S., Vandenbrink, D. and Chia, S. (eds.), Industrial Policies in East Asia, Tokyo: Nomura Research Institute, pp. 255-290. 